Review

\title{
Impact of DNA and RNA Methylation on Radiobiology and Cancer Progression
}

\author{
Hsiang-Cheng Chi ${ }^{1}$, Chung-Ying Tsai ${ }^{2}$, Ming-Ming Tsai ${ }^{3,4}$ and Kwang-Huei Lin ${ }^{5,6,7, * \text { (iD) }}$ \\ 1 Radiation Biology Research Center, Institute for Radiological Research, Chang Gung University/Chang \\ Gung Memorial Hospital, Linkou, Taoyuan 333, Taiwan; hgchi@mail.cgu.edu.tw \\ 2 Kidney Research Center and Department of Nephrology, Chang Gung Immunology Consortium, \\ Chang Gung Memorial Hospital, Chang Gung University College of Medicine, Taoyuan 333, Taiwan; \\ monster_0616@yahoo.com.tw \\ 3 Department of Nursing, Chang-Gung University of Science and Technology, Taoyuan 333, Taiwan; \\ mmtsai@gw.cgust.edu.tw \\ 4 Department of General Surgery, Chang Gung Memorial Hospital, Chiayi 613, Taiwan \\ 5 Liver Research Center, Chang Gung Memorial Hospital, Linkou, Taoyuan 333, Taiwan \\ 6 Department of Biochemistry, College of Medicine, Chang-Gung University, Taoyuan 333, Taiwan \\ 7 Research Center for Chinese Herbal Medicine, College of Human Ecology, Chang Gung University of \\ Science and Technology, Taoyuan 333, Taiwan \\ * Correspondence: khlin@mail.cgu.edu.tw; Tel./Fax: +886-3-211-8263
}

Received: 22 January 2018; Accepted: 10 February 2018; Published: 12 February 2018

\begin{abstract}
Radiotherapy is a well-established regimen for nearly half the cancer patients worldwide. However, not all cancer patients respond to irradiation treatment, and radioresistance is highly associated with poor prognosis and risk of recurrence. Elucidation of the biological characteristics of radioresistance and development of effective prognostic markers to guide clinical decision making clearly remain an urgent medical requirement. In tumorigenic and radioresistant cancer cell populations, phenotypic switch is observed during the course of irradiation treatment, which is associated with both stable genetic and epigenetic changes. While the importance of epigenetic changes is widely accepted, the irradiation-triggered specific epigenetic alterations at the molecular level are incompletely defined. The present review provides a summary of current studies on the molecular functions of DNA and RNA $\mathrm{m}^{6} \mathrm{~A}$ methylation, the key epigenetic mechanisms involved in regulating the expression of genetic information, in resistance to irradiation and cancer progression. We additionally discuss the effects of DNA methylation and RNA $N^{6}$-methyladenosine $\left(\mathrm{m}^{6} \mathrm{~A}\right)$ of specific genes in cancer progression, recurrence, and radioresistance. As epigenetic alterations could be reversed by drug treatment or inhibition of specific genes, they are also considered potential targets for anticancer therapy and/or radiotherapy sensitizers. The mechanisms of irradiation-induced alterations in DNA and RNA ${ }^{6} \mathrm{~A}$ methylation, and ways in which this understanding can be applied clinically, including utilization of methylation patterns as prognostic markers for cancer radiotherapy and their manipulation for anticancer therapy or use as radiotherapy sensitizers, have been further discussed.
\end{abstract}

Keywords: radiotherapy; DNA methylation; RNA methylation; epigenetic regulation

\section{Introduction}

Radiotherapy has been established as one of the major treatment options for patients with cancer in the clinic for over 100 years, based on the theory that cancerous regions can be destroyed with targeted ionizing radiation exposure, while normal tissue parts surrounding tumor lesions can withstand and recover after radiotherapy [1]. However, accumulating evidence indicates that a 
decisive small population of radioresistant cancer cells exhibits stem cell characteristics responsible for tumor initiation, maintenance, and progression. These cancer-initiating cells, designated cancer stem cells (CSCs), are characterized by their potent tumorigenic properties and ability to self-renew [2-4]. More importantly, cancer stem cells contribute to radioresistance as well as chemoresistance, and are believed to mediate relapse and recurrence of the disease after therapy [5]. Cancer stem cell markers are reported to be epigenetically regulated [6]. For instance, DNA methylation is linked to several crucial pathways involved in CSC activation, including Wnt (Wingless-type MMTV integration site family) / $\beta$-catenin (catenin beta 1), Hh (Hedgehog), and Notch signaling [7].

Efforts to improve radiotherapeutic strategies, such as optimization of treatment plans and precision of dose delivery, are not beneficial in some cases, and inter-individual differences in therapeutic activity are commonly observed [8]. Cellular response to radiotherapy is dependent on the molecular composition of cancer cells. However, the availability of predictive biomarkers that can be used to monitor alterations in molecular composition and predict outcomes of radiotherapy is limited $[8,9]$. Combination of the clinical characteristics of patients with molecular or imaging markers may aid in the identification of prognostic factors in cancer patients treated with radiotherapy [10].

Alterations in the epigenetic patterns in the structure and function of chromosomes are heritable events that occur without changes in the DNA sequence. In mammalian cells, epigenetic changes, including DNA and RNA ${ }^{6} \mathrm{~A}$ methylation, have been implicated in several critical biological roles, including cellular proliferation, differentiation, and development of multiple organisms [11,12]. Dysregulation of epigenetic mechanisms leads to global changes in genomic packaging and specific gene promoter changes that influence the transcription of downstream genes involved in cancer progression [13]. Thus, regulation of epigenetic mechanisms has been established as an emerging strategy for cancer therapy.

Cell proliferation and survival require tight regulation and propagation of genetic material, which are attacked by both intracellular and extracellular environmental sources of DNA damage. Irradiation is considered a potent DNA damage inducer and epigenotoxic agent [14]. Within the epigenetic parameters, DNA methylation is significantly implicated in the context of radiation biology $[14,15]$. DNA methylation is one of the known epigenetic mechanisms involved in the regulation of genetic material. Recent studies have additionally demonstrated crucial roles of RNA m ${ }^{6} \mathrm{~A}$ methylation in both irradiation-triggered DNA damage response and radioresistance [16,17]. In the current review, we have provided an overview of the reported roles of DNA and RNA ${ }^{6}$ A methylation in radiobiology and cancer progression. Application of epigenetic regulators and biomarkers in radiotherapy is further discussed. Epigenetic regulators are speculated to contribute to radioresistance and metastasis of tumors. Elucidation of the molecular cues underlying the effects of epigenetic changes following irradiation should facilitate the design and development of effective strategies to improve the therapeutic effects of radiotherapy and prevent cancer recurrence.

\section{Roles of DNA Methylation in Radiotherapy and Cancer Progression}

\subsection{DNA Methylation}

DNA methylation is considered the most common mechanism regulating epigenetic events and is closely associated with the progression of several cancer types, including breast, colon, lung, and prostate cancer $[18,19]$. The process is catalyzed by DNMT (DNA methyltransferases), and usually occurs at the $5^{\prime}$ position of the cytosine ring within the $\mathrm{CpG}$ (cytosine guanine dinucleotide) island. To date, five members of the DNMT family have been identified, among which DNMT1 (DNA methyltransferase 1), DNMT3A (DNA methyltransferase 3 alpha), and DNMT3B (DNA methyltransferase 3 beta) have functional activity in mammalian cells. DNMT1 shows up to a 50-fold preference for hemimethylated DNA substrates at the CpG island after DNA replication, and is thus designated "maintenance DNMT". DNMT3A and DNMT3B generate new methylation patterns on both DNA strands during embryogenesis and development of germ cells. DNA methylation is 
implicated in gene inhibition during development, and leads to potent $\mathrm{X}$-chromosome inactivation and genetic imprinting. In addition to regulation of gene expression, DNA methylation protects cells from chromosomal instability through inhibition of endogenous retroviral and parasitic repetitive sequences [20]. Additionally, alterations in DNA methylation patterns that appear to contribute to cancer progression have been extensively documented. For instance, DNA hypermethylation of cancer cells may present an alternative complementary mechanism to trigger mutation or silencing of specific genes, consequently leading to acquisition of tumorigenic behavior, including cellular survival and metastasis $[13,18]$. In addition to DNA hypermethylation, the genetic material of cancer cells undergoes a global decrease in 5-methylcytosine levels. The overall hypomethylation of the genetic material influences intergenic and intronic DNA, repetitive, and transposable elements especially, leading to loss of imprinting, chromosomal instability, and reactivation of endogenous parasitic sequences [21]. Radiotherapy plays a crucial role in the curative treatment of various malignancies, and radioresistance is highly associated with poor prognosis and relapse of cancers [22]. Mounting evidence indicates that irradiation treatment may lead to aberrantly altering DNA methylation patterns, and radiation-induced epigenetic changes may contribute to the initiation of radioresistance [23].

\subsection{Ionizing Radiation and Global DNA Methylation}

The effects of radiotherapy on genetic alterations have been extensively documented [24-26]. However, epigenetic alterations induced by irradiation, even those causing changes in transcriptional activity and cellular resistance to radiation therapy, remain to be clarified [14,15]. The earliest research interest on the impact of irradiation on DNA methylation was traced back to 1972 when an overall increase in DNA methylation was observed in Escherichia coli 15T following irradiation [27]. Subsequent experiments showed that irradiation triggers dynamic changes in DNA methylation, with patterns of DNA hyper- and hypo-methylation observed in the thymus and bone marrow of Wistar rats [28]. Moreover, the level of 5-methylcytosine was significantly decreased in several organs and cancer cell types, including ovarian, lung fibroblasts, HeLa, and neuroblastoma cells [29]. Follow-up studies have suggested that the levels of change in DNA methylation in response to irradiation are dose- and tissue-dependent. For instance, global DNA methylation is decreased in liver thymus, spleen, bone marrow, and mammary gland, but not muscle and lung [30-34]. Irradiation-induced global hypomethylation, in vitro and in vivo, possibly occurs as a result of decreased expression of DNA methyltransferases or methyl-CpG binding proteins, including DNMT1, DNMT3A/3B, MBD2 (methyl-CpG binding domain protein 2), and MECP2 (methyl-CpG binding protein 2) [35-37]. These effects are more apparent after fractionated irradiation, and are sex- and tissue-dependent [38], and appear persistent, even after repair of irradiation-triggered DNA damage $[33,34,36,39,40]$.

\subsection{Gene-Specific DNA Methylation as a Potential Predictor of Response to Radiotherapy}

As global hypomethylation is linked to malignant transformation and carcinogenesis, DNA hypomethylation triggered by radiation therapy may be utilized as a marker of oncogenic transformation [33,34]. In addition to causing global changes, radiation induces alterations in methylation locus-specific regions [41,42]. DNA methylation at promoter regions of specific genes thus shows prognostic potential, and may present effective markers to predict the outcomes of radiotherapy (Table 1). 
Table 1. Summary of the relevant DNA methylation of genes associated with radiotherapy/response in various cancers.

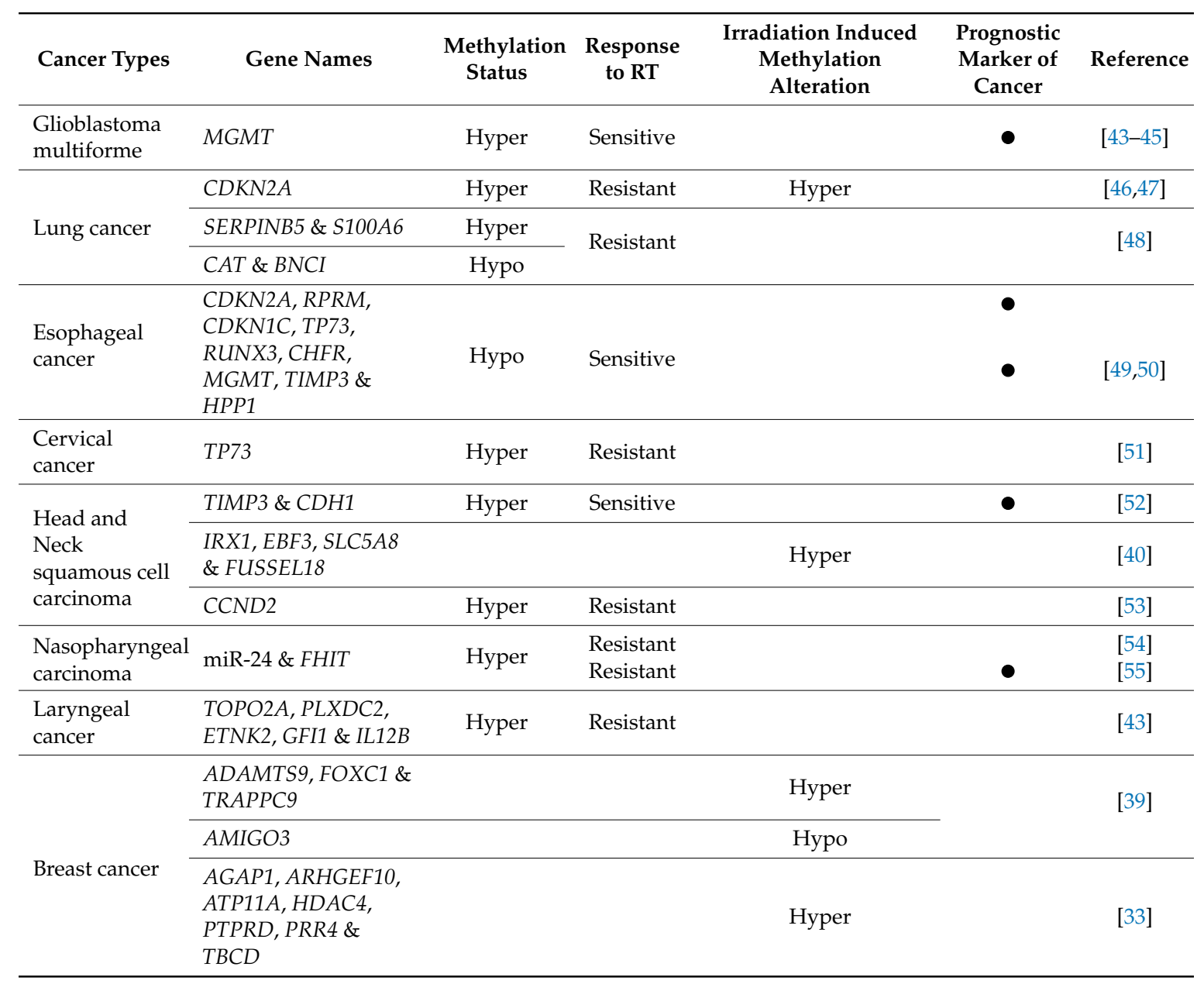

๑: determined; RT: radiotherapy.

\subsubsection{Glioblastoma Multiforme (GBM)}

The methylation level of the promoter of $M G M T\left(O^{6}\right.$-methylguanine-DNA methyltransferase), a radiation-induced gene that encodes a DNA repair enzyme responsible for removing alkyl groups from guanine, was identified as a predictive epigenetic biomarker in glioblastoma $[43,44,56]$. Patients with hypermethylation of the MGMT promoter have been shown to display better survival following adjuvant chemotherapy or radiotherapy $[45,57,58]$. This finding may be attributable to hypermethylation-driven suppression of MGMT expression, and consequent blockage of the inhibitory effects on the chemotherapeutic activity of drugs or irradiation in tumor killing. In contrast to data obtained from patients with glioblastoma, the methylation level of the MGMT promoter was associated with poorer prognosis or higher chance of relapse after chemo- or radiotherapy in other solid tumors, such as cervical cancer and non-small-cell lung cancer patients with brain metastasis [46,59].

\subsubsection{Lung Cancer}

Significant DNA hypermethylation of MGMT and CDKN2A (cyclin-dependent kinase 2A) genes in sputum of uranium miners was previously reported [60]. These genes are frequently hypermethylated and inactivated during tumor progression, particularly in lung cancer $[47,61]$. Further studies revealed higher methylation levels of CDKN2A in lung adenocarcinomas from plutonium-exposed workers, compared to non-exposed workers at MAYAK, a Russian nuclear 
enterprise [48]. Hypermethylation-driven silencing of $C D K N 2 A$ expression has also been observed in a murine model of radiation-induced thymic lymphoma [49]. Aberrant methylation of CDKN2A is therefore proposed as a potentially useful marker to predict tumor cell response to chemo- and radiotherapy. In non-small cell lung cancer (NSCLC), global analysis of CpG methylation has been used to determine the factors associated with epigenetic control of radiosensitivity. In a study by Kim et al. [62], a higher proportion of hypermethylation was observed in radioresistant NSCLC cells, and 1091 differentially methylated genes were identified, among which, 747 were hypermethylated and 344 were hypomethylated. Furthermore, hypermethylated genes were implicated in multiple processes, including regulation of inter- and intra-cellular signaling, while most of the hypomethylated genes were implicated in transcriptional control. Among the genes displaying the most significant differences in methylation, SERPINB5 (serpin family B member 5) and S100A6 (S100 calcium binding protein A6) hypermethylation, and $C A T$ (catalase) and BNC1 (basonuclin 1) hypomethylation were implicated in radioresistance of NSCLC. Data from this study suggest that response to irradiation is highly dependent on the overall methylation profile of tumors [62].

While these studies clearly suggest a role for epigenetic biomarkers in determining response to radiotherapy, the prognostic value of the potential markers identified requires validation in large patient populations to ensure their clinical utility.

\subsubsection{Esophageal Cancer}

In esophageal cancer, CDKN2A, RPRM (reprimo), CDKN1C (cyclin dependent kinase inhibitor 1C), TP73 (tumor protein p73), RUNX3 (runt related transcription factor 3), CHFR (checkpoint with forkhead and ring finger domains), MGMT, TIMP3 (TIMP metallopeptidase inhibitor 3), and HPP1 (hyperpigmentation, progressive, 1) comprise a marker panel showing decreased methylation in radiation-responsive patients. Conversely, increased methylation of these genes is significantly correlated with poor responsiveness to chemoradiation [63]. Runt-related transcription factor 3 (RUNX3), a tumor suppressor that mediates transforming growth factor TGF- $\beta$ (Transforming growth factor beta) dependent apoptosis [50,51], is reported to be hypermethylated and downregulated in radioresistant esophageal cancer cells. Both RUNX3 expression and methylation levels in pretreatment specimens may be applied to predict radiosensitivity of esophageal squamous cell carcinomas [52].

\subsubsection{Cervical Cancer}

TP73, a member of the p53 family of transcription factors involved in cellular responses to stress and development, is hypermethylated in radioresistant cervical cancers, and significantly associated with silencing of p73 expression [53]. Higher p73 expression is positively associated with radiosensitivity of cervical cancer cells, and may play an important role in regulating the radioresponse of tumors.

\subsubsection{Head and Neck Squamous Cell Carcinoma (HNSCC)}

In patients with advanced head-and-neck squamous cell carcinoma (HNSCC) treated solely with radiotherapy, promoter hypermethylation-driven silencing of TIMP3, an inhibitor of matrix metalloproteinases, and CDH1 (cadherin 1), a calcium-dependent cell-cell adhesion protein, have been identified as markers to predict better therapeutic outcome [54]. Another study identified five frequently methylated tumor suppressor genes, including IRX1 (iroquois homeobox 1), EBF3 (early B cell factor 3), SLC5A8 (solute carrier family 5 member 8), SEPT9 (septin 9), and SKOR2 (SKI family transcriptional corepressor 2), in HNSCC following radiotherapy. Alterations in methylation of promoters of this subset of genes were enriched in pathways implicated in radiation responses, including cell cycle regulation, DNA repair, and apoptosis [42]. A recent study using Human Methylation450 BeadChip, in combination with gene expression profile analysis, identified 84 differentially expressed genes that display differential methylation levels between radioresistant and radiosensitive HNSCC cells. Data from this investigation disclosed significantly increased DNA 
methylation in radiation-resistant cells. Notably, the differentially methylated and expressed genes in radioresistant cells were implicated in the regulation of integrin-linked kinase and glucocorticoid receptor cascades, fatty acid catabolism, and cell proliferation. Further validation studies indicated that cyclin D2 (CCND2), a potent cell cycle regulator, is hypermethylated at the promoter region, and downregulated in radioresistant head and neck squamous cells [55].

\subsubsection{Nasopharyngeal Carcinoma (NPC)}

Radiotherapy is the standard therapy of choice for nasopharyngeal carcinoma (NPC), and aberrant DNA methylation is known to be involved in NPC response to radiotherapy. A recent study reported that inactivation of miR-24 through hypermethylation of its precursor promoter is associated with NPC radioresistance. Furthermore, treatment with 5-aza-2'-deoxycytidine compensated for reduced miR-24 expression and sensitized radioresistant NPC cells to therapy [64].

FHIT (Fragile histidine triad) gene, a triphosphate hydrolase involved in purine metabolism, is hypermethylated and consequently silenced in established radioresistant oral cancer cells [65]. Further in vivo experiments confirmed that inhibition of DNA methylation of FHIT leads to significant resensitization of the radioresistant oral tumors. Furthermore, hypermethylation of the FHIT promoter was inversely correlated with its expression, and served as an independent predictor of both overall survival and locoregional control in oral cancer patient samples. These data suggest that expression and hypermethylation-driven silencing of FHIT are the determining factors for radiosensitivity in oral cancer.

\subsubsection{Laryngeal Cancer}

Another study used radioresistant laryngeal cancer cells established via long-term fractionated irradiation to identify the crucial genes with DNA hypermethylation involved in radioresistance of cancer. Increased methylation levels of promoters of TOP2A (DNA topoisomerase II alpha), PLXDC2 (plexin domain containing 2), ETNK2 (ethanolamine kinase 2), GFI1 (growth factor independent 1 transcriptional repressor), and IL12B (interleukin 12B) were detected in radioresistant laryngeal cancer cells. Elimination of methylation of TOP2A by treatment with the DNA methyltransferase inhibitor, 5-aza-2'-deoxycytidine, not only sensitized resistant laryngeal cancer cells to radiotherapy, but re-activated expression of these genes, clearly supporting the theory that changes in DNA methylation levels contribute to radioresistance of laryngeal squamous cell carcinoma [45].

\subsubsection{Breast Cancer}

The effects of fractioned ionizing radiation at a dose of $2 \mathrm{~Gy}$ with cumulative doses of 10 and $20 \mathrm{~Gy}$ on DNA methylation in the human breast cancer cell line, MCF7, were examined [41]. Cells were harvested $48-72 \mathrm{~h}$ after the final irradiation, as well as the recovery period of up to 24 days. A subset of genes was differentially methylated in response to radiation treatment. Specifically, increased methylation was observed in ADAMTS9 (ADAM metallopeptidase with thrombospondin type 1 motif 9), FOXC1 (forkhead box C1), and TRAPPC9 (trafficking protein particle complex 9), while the methylation level of $A M I G O 3$ (adhesion molecule with Ig like domain 3) was decreased in response to radiation. Further in vitro experiments showed significant methylation loss in FOXC1 and TRAPPC9 after a recovery period in which irradiated cells displayed regrowth, compared to control cells. As both genes are implicated in cell death control, alterations in their DNA methylation patterns may lead to reduced apoptotic signaling, resulting in regrowth of breast cancer cells after radiation [41]. Antwih et al. [35] globally analyzed DNA methylation changes at $>450,000$ loci in breast cancer MDA-MB-231 cells subjected to X-ray irradiation. Their findings suggest that that differentially methylated genes (for instance, AGAP1 (ArfGAP with GTPase domain, ankyrin repeat and PH domain 1), ARHGEF10 (Rho guanine nucleotide exchange factor 10), ATP11A (ATPase phospholipid transporting 11A), HDAC4 (histone deacetylase 4), PRR4 (proline rich 4), PTPRD (protein tyrosine phosphatase, receptor type D), and TBCD (tubulin folding cofactor D)) in MDA-MB-231 cells induced 
by irradiation exposure are enriched in pathways related to control of the cell cycle, DNA repair, and apoptosis.

\subsubsection{Cancer Stem Cells}

As intrinsic cancer stem cells (CSCs) are responsible for radioresistance and metastasis in various cancer types [2,66-68], radiation-induced alterations in DNA methylation in this cell population are particularly interesting. A recent report showing that mouse embryonic stem cells do not exhibit changes in DNA methylation levels after radiation suggests that global levels of methylation in stem cells are not determinants of radiosensitivity [69]. However, alterations in DNA methylation levels were observed in offspring of radiation-treated mice [70,71]. These findings indicate that epigenetic changes are transmitted through the germline and cause genomic destabilization, representing a possible cause of cancer [70]. Another study combined irradiation with 5-aza-2'-deoxycytidine to improve the cancer killing effects through inhibiting proliferation and promoting apoptosis of pancreatic cancer cells, both in vitro and in vivo. Interestingly, this combinatorial effect was preferentially targeted to pancreatic CSCs through inhibition of regulatory factors of self-renewal and surface markers. Further experiments revealed significant downregulation of the OCT4 (POU class 5 homeobox 1, POU5F1)-centered transcriptional network of genes in cells in response to the combination treatment. Radiotherapy in combination with DNA methylation inhibitors may, therefore, present a novel therapeutic anti-cancer strategy [72].

\subsection{Therapeutic Potential of DNA Methylation-Targeted Drugs in Radiotherapy}

Accumulating evidence suggests that the DNA methylation landscape influences cellular responses to irradiation. This knowledge may be further utilized in modulation of the response of normal and cancerous cells to irradiation, as well as application of DNA methylation-targeted drugs as radiosensitizers.

Based on the finding that depletion of DNMTs results in global demethylation [73], several DNMT inhibitors, including the nucleoside analogs 5-azacytidine (5-aza), 5-aza-2'-deoxycytidine (decitabine), and zebularine, have been successfully used for hematological malignancies, and are currently under trial for treatment of several solid tumors [74-76]. Inhibitors of DNMT are nucleoside analogs that irreversibly bind DNMTs to DNA, thereby inhibiting their function [77]. Thus, the genes silenced via methylation can be rescued. Inhibitors of DNMT are hypothesized to influence radiosensitivity through several mechanisms. For instance, as blockers of DNA synthesis, DNMT inhibitors suppress not only DNA repair, but also the number of tumor clonogens, exerting cytotoxicity to proliferative cells following radiotherapy. Additionally, these compounds are considered a trigger of apoptosis [78]. Mounting evidence indicates that utilization of nucleoside analogs increases the sensitivity of various cancer types to radiotherapy, including gastric [79], colorectal [80], head and neck, nasopharyngeal [80], and brain cancer [81]. Moreover, removal of DNMT inhibitors led to recovery of radioresistance to previous levels for all cancer types, except DNMT-deficient tumor cells. For instance, HCT116, a colorectal cell line deficient in DNMT3B and DNMT3B/DNMT1 ${ }^{-/-}$, displayed a trend of increased radiosensitivity, which was not observed in DNMT1-deficient cells [80].

As aza and decitabine are relatively toxic to normal cells and cannot be administered orally, other DNMT inhibitors, such as zebularine and 5-fluoro-2'-deoxycytidine, have been developed [77] that are also closely related to radiosensitivity [78,81].

Despite the promising results, the majority of data have been generated from in vitro studies so far, and several concerns regarding the safety of radiation treatment in combination with DNMT inhibitors to healthy tissue need to be addressed. Demethylating agents also cause hypomethylation of normal tissue, which may influence radiation-induced abscopal effects, risk of secondary tumor development, and virus reactivation (e.g., Epstein-Barr virus) [80,82]. Moreover, a number of in vitro and in vivo studies have indicated that AZA and decitabine cause chromosomal instability, decreased fertility, and loss of offspring [78]. To address these issues, non-nucleoside inhibitors have recently been developed 
that target DNMT directly without incorporation into DNA. These compounds display demethylating activity both in vitro and in vivo, and are currently undergoing clinical trials [81]. Further in vivo and clinical studies are required to resolve the multiple problems and clarify the biological mechanisms underlying the effects of DNMT inhibitors on radiosensitivity.

\section{Roles of RNA $\mathrm{m}^{6} \mathrm{~A}$ Methylation in Radiotherapy and Cancer Progression}

Analogous to DNA methylation, RNA methylation occurs at the $N^{6}$ position of adenosine $\left(\mathrm{m}^{6} \mathrm{~A}\right)$ of transcripts, leading to context-dependent perturbations in the duplex structure. $\mathrm{m}^{6} \mathrm{~A}$, initially identified in 1974 [83], is the most widespread base modification of all RNA types, including mRNA, ncRNA, snoRNA, tRNA, rRNA, and others, accounting for $\sim 0.2-0.6 \%$ of all adenosines in mammalian mRNA and over three sites within a $\mathrm{G}\left(\mathrm{m}^{6} \mathrm{~A}\right) \mathrm{C}(70 \%)$ or $\mathrm{A}\left(\mathrm{m}^{6} \mathrm{~A}\right) \mathrm{C}(30 \%)$ consensus sequence per transcript [84-86]. $\mathrm{m}^{6} \mathrm{~A}$ on mRNA is installed, recognized, and erased post-transcriptionally through $\mathrm{m}^{6} \mathrm{~A}$ methyltransferases (writer) [87-91], demethylases (eraser) [92,93], and $\mathrm{m}^{6} \mathrm{~A}$-specific binding proteins (readers) [94,95]. High-throughput sequencing revealed that distribution of $\mathrm{m}^{6} \mathrm{~A}$ in mature transcripts is not random, but mainly occurs in the $5^{\prime}, 3^{\prime}$ untranslated regions (5'-, $3^{\prime}$-UTR) and within internal long exons [96-98], consequently influencing the procession and function of RNAs, including RNA stability $[99,100]$, mRNA translation [101-103], alternative splicing $[104,105]$ and polyadenylation [106]. Due to the crucial roles of RNA in genetic regulation, RNA $\mathrm{m}^{6} \mathrm{~A}$ patterns play important roles in regulating biological functions of mammalian and cancer cells $[12,107,108]$. Various issues on RNA methylation and demethylation in relation to cancer therapy and progression remain to be clarified. Recently, $\mathrm{m}^{6} \mathrm{~A}$ in RNA was shown to be involved in the DNA damage response following irradiation [17]. Since the treatment effects of radiation mainly rely on DNA damage, $\mathrm{m}^{6} \mathrm{~A}$ in RNAs involved in the damage response and repair processes of tumor cells potentially have significant effects on the outcomes of radiotherapy.

CSCs are a crucial contributor to radioresistance and disease recurrence after radiotherapy in the majority of cancers [2-4]. Notably, $\mathrm{m}^{6} \mathrm{~A}$ modification is involved in CSC generation and radioresistance of tumor cells. Thus, manipulation of inhibitors or inducers of $\mathrm{m}^{6} \mathrm{~A}$ modifications could be advantageous in the treatment of radioresistant tumor cells [109].

\section{1. $m^{6} A$ Methyltransferases ( $m^{6} A$ Writers)}

$\mathrm{m}^{6} \mathrm{~A}$ formation within mRNA is catalyzed by the $\mathrm{m}^{6} \mathrm{~A}$ writers containing catalytically active METTL3 (methyltransferase-like 3)-METTL14 (methyltransferase-like 14) complex and other associated proteins [87]. WTAP (Wilms' tumor 1-associating protein), VIRMA (vir-like $\mathrm{m}^{6} \mathrm{~A}$ methyltransferase associated), RBM15 (RNA binding motif protein 15), and RBM15B/OTT3 (RNA-binding motif protein 15B) are established partners of METTL3. METTL3 contains a catalytically active methyltransferase domain that methylates mRNA, but not rRNA [110]. METTL14 is an active component of the $\mathrm{m}^{6} \mathrm{~A}$ methyltransferase complex that forms a heterocomplex with METTL3 [91,111]. Biochemical analyses have revealed that METTL3 and METTL14 form a stable complex at a stoichiometric ratio of 1:1 [112]. The methylation activity of METTL14 is only slightly higher than that of METTL3 in vitro. Interestingly, however, the heterodimer of METTL3 and METTL14 exhibits enhanced methylation efficiency. In addition, METTL14 serves as an RNA adaptor protein to enhance the methyltransferase activity of the $\mathrm{m}^{6} \mathrm{~A}$ writer complex.

Homologous genes of WTAP were initially identified in Arabidopsis thaliana and yeast, and shown to be associated with the METTL3-METTL14 complex $[113,114]$. This $\mathrm{m}^{6} \mathrm{~A}$ writer localizes in nuclear speckles to participate in RNA methylation and processing $[88,91,115,116]$. Due to the lack of an active catalytic methylation domain, WTAP does not possess methylation activity, but interacts with METTL3-METTL14 heterodimer to influence the RNA $\mathrm{m}^{6} \mathrm{~A}$ load in cells.

RBM15 and its paralog RBM15B associate with METTL3 in a WTAP-dependent manner [92,117]. Both RBM15 and RBM15B contain RNA-binding domains that facilitate writer complex binding to 
specific mRNAs. For instance, RBM15 and RBM15B guide the $\mathrm{m}^{6} \mathrm{~A}$-methylation complex to lncRNA X-inactive specific transcript (XIST) for consequent repression [118].

Recently, METTL16 was identified as an RNA methyltransferase that exerts its functions independently of the $\mathrm{m}^{6} \mathrm{~A}$ writer complex containing METTL3 $[119,120]$. The protein acts as a conserved U6 snRNA methyltransferase, and displays an additional function in vertebrates in regulating the homeostasis of $S$-adenosylmethionine (SAM) by modulating alternative splicing of $M A T 2 A$ (methionine adenosyltransferase 2A) through differential methylation of mRNA hairpin loops [119].

\section{2. $m^{6} A$ Demethylase ( $m^{6} A$ Erasers)}

Fat mass and obesity-associated protein (FTO) is a member of the AlkB (Alkylation repair homologs) subfamily of $\mathrm{Fe}(\mathrm{II}) /$ alpha-ketoglutarate-dependent dioxygenases, and was originally described as an eraser of $\mathrm{m}^{6} \mathrm{~A}$ modifications in RNA. FTO was initially reported to demethylate single-stranded DNA (ssDNA) and single-stranded RNA (ssRNA) via removal of $N^{3}$-methylthymidine [121,122]. Further experiments revealed that silencing of FTO in HeLa and 293FT cells leads to an increase in total $\mathrm{m}^{6} \mathrm{~A}$ in polyadenylated RNA, while its overexpression causes a decrease in $\mathrm{m}^{6} \mathrm{~A}$ levels [92,117]. Recently, FTO was identified as an eraser for the $N^{6}$, $2^{\prime}$-O-dimethyladenosine $\left(\mathrm{m}^{6} \mathrm{Am}\right)$ modification co-detected with $\mathrm{m}^{6} \mathrm{~A}$ [123]. Advanced detection techniques could effectively differentiate between $\mathrm{m}^{6} \mathrm{~A}$ and $\mathrm{m}^{6} \mathrm{Am}$ to facilitate detailed examination of the substrate spectrum of FTO. Biochemical analyses revealed that $\mathrm{m}^{6} \mathrm{Am}$ is the preferred cellular target of FTO in vivo [123]. FTO contains a unique C-terminal domain, distinct from that of other proteins in the AlkB family [121,124], which engages in additional protein-RNA and protein-protein interactions that influence the function of the protein $[125,126]$.

ALKBH5 (AlkB homolog 5) is another mammalian demethylase belonging to the AlkB subfamily with efficient demethylation activity on $\mathrm{m}^{6} \mathrm{~A}$ in mRNA. ALKBH5 contains an alanine-rich sequence and potential coiled-coil structure within the N-terminal region that is responsible for its nuclear localization [126]. Structural analyses revealed a putative region contributing to binding of dsDNA. Moreover, silencing of ALKBH5 is reported to impair both mRNA export and processing in nuclear speckles [99,101,127,128]. ALKBH5 participates in multiple physiological functions, including fertility, cell survival, and apoptosis, via regulating stability, splicing, subcellular localization, and translation efficiency of mRNA $[12,84,93,129]$.

\section{3. $m^{6} A$ Binding Proteins ( $m^{6} A$ Readers)}

$\mathrm{m}^{6} \mathrm{~A}$ methylations of RNAs are mainly read by eukaryotic initiation factor 3 (eIF3) and proteins containing a YT521-B homology (YTH) domain belonging to the YTH protein family. However, several RNA binding proteins (RBP) that associate with $\mathrm{m}^{6} \mathrm{~A}$ do not belong to the classical $\mathrm{m}^{6} \mathrm{~A}$ YTH domain family. YTHDF1 (YTH $N^{6}$-methyladenosine RNA binding protein 1), YTHDF2 (YTH $N^{6}$-methyladenosine RNA binding protein 2), YTHDF3 (YTH $N^{6}$-methyladenosine RNA binding protein 3), YTHDC1 (YTH domain containing 1), and YTHDC2 (YTH domain containing 2), members of the YTH domain family, represent the predominant cytoplasmic $\mathrm{m}^{6} \mathrm{~A}$ reader proteins [94]. Proteins of the YTH domain family preferentially bind RNA with $\mathrm{m}^{6} \mathrm{~A}$ at the $(\mathrm{G}>\mathrm{A}) \mathrm{m}^{6} \mathrm{ACU}$ consensus sequence, compared to unmethylated RNA of the same transcript [95]. YTHDF2 is the first characterized $\mathrm{m}^{6} \mathrm{~A}$ reader protein shown to mediate RNA decay by targeting RNA substrates to P-bodies in an $\mathrm{m}^{6} \mathrm{~A}$-dependent manner $[130,131]$. YTHDF1 and YTHDF3 are proposed to modulate translation machinery, and consequently influence the translation efficacy of target mRNAs [132-134].

Nuclear YTH domain-containing 1 (YTHDC1), also designated YT521-B, has been identified as a nuclear $\mathrm{m}^{6} \mathrm{~A}$ reader that binds $\mathrm{m}^{6} \mathrm{~A}$ through tryptophan residues at positions 377 and 428 by forming an aromatic cage [135]. A glutamic acid-rich region of the amino terminus and glutamic acid / arginine-rich regions of the carboxyl terminus of YTHDC1 are responsible for nuclear localization and formation of YT bodies [136]. Due to the proximity of YT bodies to nuclear speckles, YTHDC1 
may access nascent mRNA, and subsequently facilitate recruitment of RNA splicing factors to regulate pre-mRNA splicing [137].

Nuclear YTH domain-containing 2 (YTHDC2) was initially reported as a factor required for $\mathrm{HCV}$ genome replication [138]. This factor is widely expressed in human cells and shown to promote cancer metastasis through enhancing translation of hypoxia-inducible factor- $1 \alpha$ (HIF- $1 \alpha)$ and TWIST (Twist family bHLH transcription factor 1) [139]. Recently, YTHDC2 was reported as an $\mathrm{m}^{6} \mathrm{~A}$ reader essential for male and female fertility in mice via regulation of the $\mathrm{m}^{6} \mathrm{~A}$ transcriptome. Additionally, this factor is highly expressed in germ cells, and interacts with an essential meiosis-specific protein, MEIOC (meiosis specific with coiled-coil domain) [140].

Other than the YTH domain family, pulldown assays revealed that heterogeneous nuclear ribonucleoprotein A2/B1 (HNRNPA2B1) binds $\mathrm{m}^{6} \mathrm{~A}$ in the nucleus [94]. Another study consistently demonstrated that HNRNPA2B1 interacts with the $\mathrm{m}^{6} \mathrm{~A}$ site of RNA transcripts, and regulates splicing and maturation of microRNA (miRNA) [141].

Eukaryotic initiation factor 3 (eIF3), a protein complex that functions in the initiation of eukaryotic translation, has additionally been identified as an important $\mathrm{m}^{6} \mathrm{~A}$ binding protein. Following binding to $\mathrm{m}^{6} \mathrm{~A}$ in the $5^{\prime}$-UTR of RNA transcripts, initiation of translation can be triggered by eIF3 in a $5^{\prime}$ cap- and eukaryotic initiation factor 4E (eIF4E)-independent mechanism [142]. These findings support an alternative mechanism of translational initiation mediated via $\mathrm{m}^{6} \mathrm{~A}$ modifications in $5^{\prime}$-UTRs of mRNA when eIF4-dependent initiation is hindered by specific cell states. Furthermore, $\mathrm{m}^{6} \mathrm{~A}$ has been shown to influence the secondary structure of RNAs through binding of regulatory proteins, consequently modulating the expression or maturation of RNA transcripts [143-145].

For instance, secondary structure changes induced via $\mathrm{m}^{6} \mathrm{~A}$ modification facilitate binding of HNRNPC (heterogeneous nuclear ribonucleoprotein C) and RBMX (RNA binding motif protein, X-linked) for targeting and regulation of mRNA expression and splicing [146].

\section{4. $m^{6}$ A-Mediated Cancer Progression or Radioresistance}

\subsubsection{Glioblastoma Multiforme (GBM)}

Glioblastoma multiforme (GBM) is the most aggressive glioma type, affecting 17,000 patients per year. Treatment failure of glioblastoma may be due to tumor heterogeneity and treatment resistance of cancer stem cells, triggering disease recurrence [22,147]. Several studies have indicated that $\mathrm{m}^{6} \mathrm{~A}$ in RNA is associated with tumorigenesis and progression of glioblastoma $[109,148]$. Overexpression of METTL3 or inhibition of the RNA demethylase, FTO, is known to suppress GSC growth and self-renewal. Moreover, suppression of FTO causes tumor regression and promotes survival rates in GSC-grafted mice. Several oncogenes, including ADAM19 (ADAM metallopeptidase domain 19), EPHA3 (EPH receptor A3), and KLF4 (Kruppel like factor 4), are upregulated in METTL3 or METTL14-depleted GSCs, and conversely downregulated in GSCs with METTL3 or METTL14 overexpression [109].

METTL3-mediated $\mathrm{m}^{6} \mathrm{~A}$ modification is proposed to play a crucial role in glioma stem-like cell (GSC) maintenance and dedifferentiation of glioma cells [16], based on the finding that expression of METTL3 is elevated in GSCs and attenuated in differentiated cells. Further experiments demonstrated that SOX2 is the $\mathrm{m}^{6} \mathrm{~A}$ target of METTL3. Recruitment of human antigen $\mathrm{R}(\mathrm{HuR})$ to $\mathrm{m}^{6} \mathrm{~A}$ sites was essential for SOX2 mRNA stabilization by METTL3. Notably, silencing of METTL3 enhanced sensitization of GSC to radiotherapy, and expression levels of METTL3 predicted poor survival in GBMs enriched for GSC-specific signatures [16]. Zhang et al. [148] recently reported that elevated expression of ALKBH5 in GSCs is predictive of poor patient prognosis. Moreover, ALKBH5 demethylated nascent FOXM1 (forkhead box M1) transcripts, consequently enhancing FOXM1 expression. FOXM1-AS, a lncRNA that localizes in the nucleus, has been shown to promote interactions between ALKBH5 and nascent FOXM1 transcripts. Silencing of ALKBH5 and FOXM1-AS inhibited the tumorigenic potential of GSCs via suppression of FOXM1. Thus, $\mathrm{m}^{6} \mathrm{~A}$ modifications could influence the expression 
or function of genes associated with the malignant phenotype of cancer, presenting a promising therapeutic target in the tumor.

\subsubsection{Acute Myeloid Leukemia (AML)}

Leukemias are a clinically and genetically heterogeneous group of hematopoietic disorders that begin in early blood-forming cells found in the bone marrow. Acute myeloblastic leukemia (AML) is more frequent in older patients, with diagnosis at about 70 years of age on average [149]. Genetic and epigenetic regulation processes play crucial roles in classification, risk stratification, and management of acute leukemia types [150]. Increasing numbers of gene mutations, dysregulation, and epigenetic alterations have been associated with progression of acute leukemia [151,152]. FTO, an $\mathrm{m}^{6} \mathrm{~A}$ eraser, promotes leukemic oncogene-mediated cell transformation and leukemogenesis, and suppresses all-trans-retinoic acid (ATRA)-triggered AML cell differentiation by regulating the expression of specific target genes, including ankyrin repeat and SOCS box-containing 2 (ASB2) and retinoic acid receptor a (RARA), through repressing $\mathrm{m}^{6} \mathrm{~A}$ levels in these transcripts [153]. ASB2 (ankyrin repeat and SOCS box containing 2) and RARA (retinoic acid receptor alpha) are induced during hematopoiesis and function as crucial regulators of ATRA-induced differentiation of leukemia cells. Furthermore, inhibition of FTO-mediated ASB2 and RARA suppression contributes to the response of AML cells to ATRA treatment [153]. Another report suggests that isocitrate dehydrogenase 1 or 2 (IDH1/2) mutant tumors account for $\sim 20 \%$ of AML cases, causing aberrant metabolite D-2-hydroxyglutarate (D2HG) production [154], which acts as a competitive inhibitor of FTO through suppressing the activities of alpha-ketoglutarate-dependent enzymes. In a further in vitro study, cells expressing the IDH2 mutant contained significantly higher levels of $\mathrm{m}^{6} \mathrm{~A}$ in RNA transcripts than isogenic IDH2 wild type expressing cells. Therefore, the precise roles of FTO in the pathogenesis of AML require elucidation in the context of the IDH1/2 mutation in this setting [155].

Recently, a role for METTL3 in regulating myeloid differentiation and maintaining myeloid leukemia has been reported [156,157]. Both mRNA and protein levels of METTL3 are more highly expressed in AML cells than hematopoietic stem and progenitor cells (HSPC). Additionally, depletion of METTL3 in human myeloid leukemia cell lines induces cell differentiation and apoptosis, while suppressing leukemia progression in recipient mice in vivo. Analysis of single nucleotide resolution mapping of $\mathrm{m}^{6} \mathrm{~A}$, in combination with ribosome profiling, revealed that METTL3-mediated $\mathrm{m}^{6} \mathrm{~A}$ modification promotes translation of $c-M Y C$ (MYC proto-oncogene, bHLH transcription factor), $B C L-2$ (B cell leukemia/lymphoma 2), and PTEN (phosphatase and tensin homolog) in human AML cells [156]. Another study confirmed the important roles of METTL3 in leukemia progression. The authors showed that METTL3 associates with chromatin, and localizes to the transcriptional start sites of active genes, inducing $\mathrm{m}^{6} \mathrm{~A}$ modification within the coding region of the associated mRNA transcripts, and consequently, enhancing its translation [157]. Further analyses disclosed that mutations and copy number variations of $\mathrm{m}^{6} \mathrm{~A}$ regulatory genes are strongly associated with the presence of TP53 mutations in AML patients [158]. These results suggest that genetic alterations of $\mathrm{m}^{6} \mathrm{~A}$ regulatory genes in cooperation with TP53 contribute to the pathogenesis and maintenance of AML, and provide a rationale for therapeutic targeting of METTL3 in myeloid leukemia.

\subsubsection{Lung Cancer}

Lung cancer is the most commonly diagnosed cancer type and the leading cause of cancer-related mortality worldwide, with a $<15 \% 5$-year survival rate, despite the progressive improvements in standard therapies [159]. METTL3 is significantly upregulated in lung cancer, in turn, promoting cellular proliferation, survival, and metastasis. In human lung cancer cells, METTL3 promotes the translation of specific genes, such as EGFR (epidermal growth factor receptor) and Hippo pathway effector, TAZ (tafazzin), through recruitment of eIF3 to the translation initiation complex. Although $\mathrm{m}^{6} \mathrm{~A}$ is implicated in regulation of translation through binding YTHDF1 [134], another model has been proposed in which METTL3 enhances both cap-binding proteins 80 and 20 (CBP80/20), 
and eIF4E-dependent translation via binding to a specific subset of transcripts, and helping to recruit eIF3 to translation. Moreover, an independent pathway of mRNA-ribonucleoprotein complexes' remodeling may entail replacement of METTL3 with YTHDF1 at the $\mathrm{m}^{6} \mathrm{~A}$ methylated sites, and enhance the translation of a distinct subset of genes, including those encoding EGFR and TAZ.

\subsubsection{Hepatocellular Carcinoma (HCC)}

HCC is the fifth most prevalent malignant tumor, and third leading cause of cancer-related deaths worldwide [160]. Recent investigations of $\mathrm{m}^{6} \mathrm{~A}$-related mechanisms in HCC have provided new ideas for treatment. Silencing of METTL14 decreases the $\mathrm{m}^{6} \mathrm{~A}$ level in RNA transcripts and enhances cancer metastasis, both in vitro and in vivo [161], and downregulation of METTL14 in HCC serves as an adverse prognostic factor for recurrence-free survival. METTL14 has been shown to interact with the microprocessor protein, DGCR8 (DGCR8, microprocessor complex subunit), and modulate primary processing of microRNA-126 in an $\mathrm{m}^{6} \mathrm{~A}$-dependent manner. These findings suggest that METTL14 participates in the regulation of microRNAs in tumor biology, and highlight its potential as a therapeutic target in HCC [161].

In addition, METTL3 is overexpressed in HCC, and associated with poor prognosis. Silencing of METTL3 is reported to suppress tumorigenesis and progression of HCC, and conversely, its overexpression significantly promotes HCC growth, both in vitro and in vivo. Further experiments revealed that METTL3 induces $\mathrm{m}^{6} \mathrm{~A}$ modification of the SOCS2 transcript, and consequently decreases its stability in a YTHDF2-dependent manner [162].

Another recent study demonstrated that YTHDF2 expression is closely associated with malignancy of HCC, and negatively correlated with miR-145 [163]. Bioinformatics and functional assays further revealed that miR-145 targets the 3'-UTR of YTHDF2 mRNA, and inhibits its expression in HCC. Moreover, overexpression of miR-145 induced a strong increase in $\mathrm{m}^{6} \mathrm{~A}$ levels which could be blocked upon YTHDF2 overexpression [163]. These studies strongly suggest that not only methyltransferases and demethyltransferases, but also readers of $\mathrm{m}^{6} \mathrm{~A}$, control the global $\mathrm{m}^{6} \mathrm{~A}$ level in cells to influence cancer progression.

\subsubsection{Breast Cancer}

Breast cancer is the most common cancer type, and the fourth leading cause of cancer-related deaths among women worldwide [164]. Tumor hypoxia, a common phenomenon in the majority of malignant tumors, is a condition whereby tumor cells are deprived of oxygen, causing advanced but dysfunctional vascularization, and acquisition of epithelial-to-mesenchymal transition phenotype that results in cell metastasis, the major cause of breast cancer related mortality [165]. Exposure of breast cancer cells to hypoxia promotes the ALKBH5-mediated demethylation of $\mathrm{m}^{6} \mathrm{~A}$ in NANOG transcripts, consequently enhancing NANOG expression. NANOG is a potent pluripotency factor that stimulates CSC maintenance. Similar to hypoxia exposure, overexpression of ALKBH5 not only decreases NANOG mRNA methylation, but also increases NANOG (Nanog homeobox) levels, resulting in elevation of the CSC population in breast cancer [166]. Exposure to hypoxia also induces ZNF217 (zinc finger protein 217)-dependent inhibition of $\mathrm{m}^{6} \mathrm{~A}$ methylation of NANOG and KLF4 transcripts, both important pluripotency factors that mediate CSC maintenance, in turn, influencing cancer radiosensitivity and recurrence [167]. Therefore, hypoxia of cancers may stimulate pluripotency factor expression and CSC maintenance through regulation of RNA methylation.

\subsubsection{Renal Cell Carcinoma (RCC)}

Renal cell carcinoma (RCC) is currently the ninth most common cancer type in men and 14th most common in women globally [168]. The mortality rate of RCC has continuously increased by $\sim 1.5-5.9 \%$ per year [169]. Recent experiments showed that METTL3 is downregulated in clinical specimens of RCC, and negatively associated with larger tumor size and higher pathological grade. Notably, RCC patients positive for METTL3 expression had a better survival rate. Moreover, METTL3 was 
associated with regulation of cellular proliferation, migration, and metastasis through the EMT and PI3K-Akt-mTOR pathways in RCC. The collective findings suggest that loss of METTL3 expression serves as a marker for tumorigenesis, development, and survival of RCC [170].

\subsubsection{Cervical Cancer}

Cervical cancer is one of the most prevalent gynecological malignancies worldwide [171,172]. A recent analysis of $\mathrm{m}^{6} \mathrm{~A}$ mRNA methylation levels in 286 pairs of cervical cancer samples disclosed significant downregulation in cervical cancer and negative correlation with characteristics of malignancy, including pathologic stage, tumor size, differentiation, lymph invasion, and cancer recurrence. Suppression of the $\mathrm{m}^{6} \mathrm{~A}$ level, via FTO or ALKBH5 overexpression, promoted proliferation of cervical cancer cells, whereas increasing the $\mathrm{m}^{6} \mathrm{~A}$ level led to significant suppression of tumor development, both in vitro and in vivo. Thus, inhibition of the $\mathrm{m}^{6} \mathrm{~A}$ level is tightly associated with cervical cancer progression, and regulators of $\mathrm{m}^{6} \mathrm{~A}$ mRNA methylation present potential therapeutic targets in cervical cancer [173].

\subsection{Clinical Application of $m^{6} \mathrm{~A}$}

Cancer stem cells (CSC) represent a subpopulation of cancer cells with the capacities of radioresistance, metastasis, and tumor initiation in various cancer types [2,66-68]. As crucial regulators of $\mathrm{m}^{6} \mathrm{~A}$ in RNAs play important roles in cancer stem cell maintenance and progression, targeting of $\mathrm{m}^{6} \mathrm{~A}$ editing may present an effective treatment strategy. For instance, inhibition of the RNA demethylase, FTO, suppresses GSC growth and self-renewal, consequently suppressing tumor progression of GBM. Additionally, FTO exerts a critical oncogenic effect on ATRA-induced leukemic cell differentiation by decreasing $\mathrm{m}^{6} \mathrm{~A}$ levels in critical mRNA transcripts, including ASB2 and RARA [153]. Rhein, a natural compound that is neither a structural analog of $\alpha$-ketoglutaric acid nor a of metal ion-chelator, competitively targets to the active site of FTO. Data from an earlier in vitro study indicate that Rhein exerts inhibitory activity on $\mathrm{m}^{6} \mathrm{~A}$ demethylation within cells [100]. Meclofenamic acid (MA) has been developed as another selective inhibitor of FTO that acts via competitive binding to $\mathrm{m}^{6} \mathrm{~A}$-containing regions in RNAs [102]. Moreover, MA2, an ethyl ester form of MA approved by US Food and Drug Administration (FDA) as a nonsteroidal anti-inflammatory drug, serves as a competitive inhibitor of FTO [102]. Thus, Rhein, MA, or MA2 may induce tumor regression in GBM, or increase ATRA efficacy in AML through inhibiting the RNA demethylase FTO. Furthermore, citrate and IOX3 serve as inhibitors of ALKBH5, another $\mathrm{m}^{6} \mathrm{~A}$ demethylase that maintains tumorigenicity of glioblastoma stem cells $[99,127]$. However, the specificities of these inhibitors need to be validated in vivo, and development of selective inhibitors of other $\mathrm{m}^{6} \mathrm{~A}$ regulators should aid in overcoming disease recurrence and resistance to cancer therapy. In addition to FTO and ALKBH5, S-adenosylhomocysteine (SAH) acts as a kind of competitive inhibitor of adenosylmethionine-dependent methyltransferases [103]. SAH is hydrolyzed by SAH hydrolase into adenosine and homocysteine, which are important regulators of intracellular SAH levels. 3-Deazaadenosine (DAA), one of the most frequently used SAH hydrolysis inhibitors, has been shown to suppress $\mathrm{m}^{6} \mathrm{~A}$ methylation of mRNA substrates [174]. Moreover, DAA and its analogs can suppress the replication of various viruses that are capable of extensive editing of $\mathrm{m}^{6} \mathrm{~A}$-containing mRNA $[106,175]$. The effects of DAA on cancer therapy are yet to be investigated in detail.

\section{Conclusions}

Radiotherapy is one of the major forms of cancer treatment for various malignant tumor types. Radiation treatment triggers DNA damage through ionization or production of reactive oxygen species (ROS), leading to death of tumor cells, but can concomitantly promote radioresistant cancer cell metastasis and progression [22]. Accumulating evidence suggests that epigenetic alterations play important roles in radioresistance and cancer recurrence. Epigenetic approaches, including evaluation and manipulation of DNA and RNA methylation patterns, could thus present a crucial strategy to 
elucidate the biological effects of irradiation on tumors. However, the majority of documented results on the effects of irradiation on methylation of DNA or RNA are derived from in vitro and in vivo experimental systems, and limited investigations have focused on non-cancerous and tumor regions in humans to date. Thus, translational studies need to be conducted to ascertain the clinical impacts of DNA or RNA methylation on radiotherapy. However, radiation treatment is known to cause epigenetic alterations. Irradiation-induced DNA/RNA methylation markers or a marker panel may therefore be effectively utilized to predict outcomes for patients treated with radiotherapy. While no epigenetic drugs have been approved for application in humans as yet, their therapeutic benefits are clearly promising, and could be a prospective radiosensitizer in the clinic.

Acknowledgments: This work was supported by grants from Chang-Gung Memorial Hospital (CRRPD1F0011, CRRPD1F0012) and the Ministry of Science and Technology of the Republic of China (Most 103-2320-B-182-017-MY3; 103-2320-B182-018-MY3, 105-2321-B-182-002-MY3).

Author Contributions: Drafting of the manuscript: Hsiang-Cheng Chi and Chung-Ying Tsai. Critical revision of the manuscript for important intellectual content: Ming-Ming Tsai and Kwang-Huei Lin.

Conflicts of Interest: The authors declare no conflict of interest.

\section{References}

1. Delaney, G.; Jacob, S.; Featherstone, C.; Barton, M. The role of radiotherapy in cancer treatment: Estimating optimal utilization from a review of evidence-based clinical guidelines. Cancer 2005, 104, 1129-1137. [CrossRef] [PubMed]

2. Phillips, T.M.; McBride, W.H.; Pajonk, F. The response of CD24-/low $/ \mathrm{CD} 44^{+}$breast cancer-initiating cells to radiation. J. Natl. Cancer Inst. 2006, 98, 1777-1785. [CrossRef] [PubMed]

3. Piao, L.S.; Hur, W.; Kim, T.K.; Hong, S.W.; Kim, S.W.; Choi, J.E.; Sung, P.S.; Song, M.J.; Lee, B.C.; Hwang, D.; et al. CD133 ${ }^{+}$liver cancer stem cells modulate radioresistance in human hepatocellular carcinoma. Cancer Lett. 2012, 315, 129-137. [CrossRef] [PubMed]

4. Gomez-Casal, R.; Bhattacharya, C.; Ganesh, N.; Bailey, L.; Basse, P.; Gibson, M.; Epperly, M.; Levina, V. Non-small cell lung cancer cells survived ionizing radiation treatment display cancer stem cell and epithelial-mesenchymal transition phenotypes. Mol. Cancer 2013, 12, 94. [CrossRef] [PubMed]

5. Zhang, M.; Atkinson, R.L.; Rosen, J.M. Selective targeting of radiation-resistant tumor-initiating cells. Proc. Natl. Acad. Sci. USA 2010, 107, 3522-3527. [CrossRef] [PubMed]

6. Kim, J.G.; Park, M.T.; Heo, K.; Yang, K.M.; Yi, J.M. Epigenetics meets radiation biology as a new approach in cancer treatment. Int. J. Mol. Sci. 2013, 14, 15059-15073. [CrossRef] [PubMed]

7. Toh, T.B.; Lim, J.J.; Chow, E.K. Epigenetics in cancer stem cells. Mol. Cancer 2017, 16, 29. [CrossRef] [PubMed]

8. Yaromina, A.; Krause, M.; Baumann, M. Individualization of cancer treatment from radiotherapy perspective. Mol. Oncol. 2012, 6, 211-221. [CrossRef] [PubMed]

9. Popanda, O.; Marquardt, J.U.; Chang-Claude, J.; Schmezer, P. Genetic variation in normal tissue toxicity induced by ionizing radiation. Mutat. Res. 2009, 667, 58-69. [CrossRef] [PubMed]

10. Rodemann, H.P.; Wouters, B.G. Molecular and translational radiation biology/oncology: What's up? Radiother. Oncol. 2011, 99, 257-261. [CrossRef] [PubMed]

11. Jaenisch, R.; Young, R. Stem cells, the molecular circuitry of pluripotency and nuclear reprogramming. Cell 2008, 132, 567-582. [CrossRef] [PubMed]

12. Wang, S.; Sun, C.; Li, J.; Zhang, E.; Ma, Z.; Xu, W.; Li, H.; Qiu, M.; Xu, Y.; Xia, W.; et al. Roles of RNA methylation by means of $N^{6}$-methyladenosine $\left(\mathrm{m}^{6} \mathrm{~A}\right)$ in human cancers. Cancer Lett. 2017, 408, 112-120. [CrossRef] [PubMed]

13. Jones, P.A.; Baylin, S.B. The epigenomics of cancer. Cell 2007, 128, 683-692. [CrossRef] [PubMed]

14. Miousse, I.R.; Kutanzi, K.R.; Koturbash, I. Effects of ionizing radiation on DNA methylation: From experimental biology to clinical applications. Int. J. Radiat. Biol. 2017, 93, 457-469. [CrossRef] [PubMed]

15. Smits, K.M.; Melotte, V.; Niessen, H.E.; Dubois, L.; Oberije, C.; Troost, E.G.; Starmans, M.H.; Boutros, P.C.; Vooijs, M.; van Engeland, M.; et al. Epigenetics in radiotherapy: Where are we heading? Radiother. Oncol. 2014, 111, 168-177. [CrossRef] [PubMed] 
16. Visvanathan, A.; Patil, V.; Arora, A.; Hegde, A.S.; Arivazhagan, A.; Santosh, V.; Somasundaram, K. Essential role of METTL3-mediated $\mathrm{m}^{6} \mathrm{~A}$ modification in glioma stem-like cells maintenance and radioresistance. Oncogene 2018, 37, 522-533. [CrossRef] [PubMed]

17. Xiang, Y.; Laurent, B.; Hsu, C.H.; Nachtergaele, S.; Lu, Z.; Sheng, W.; Xu, C.; Chen, H.; Ouyang, J.; Wang, S.; et al. RNA $\mathrm{m}^{6} \mathrm{~A}$ methylation regulates the ultraviolet-induced DNA damage response. Nature 2017, 543, 573-576. [CrossRef] [PubMed]

18. Jones, P.A.; Baylin, S.B. The fundamental role of epigenetic events in cancer. Nat. Rev. Genet. 2002, 3, 415-428. [CrossRef] [PubMed]

19. Feinberg, A.P.; Vogelstein, B. Hypomethylation distinguishes genes of some human cancers from their normal counterparts. Nature 1983, 301, 89-92. [CrossRef] [PubMed]

20. Fratta, E.; Montico, B.; Rizzo, A.; Colizzi, F.; Sigalotti, L.; Dolcetti, R. Epimutational profile of hematologic malignancies as attractive target for new epigenetic therapies. Oncotarget 2016, 7, 57327-57350. [CrossRef] [PubMed]

21. Kulis, M.; Esteller, M. DNA methylation and cancer. Adv. Genet. 2010, 70, 27-56. [PubMed]

22. Chi, H.C.; Tsai, C.Y.; Tsai, M.M.; Yeh, C.T.; Lin, K.H. Roles of Long Noncoding RNAs in Recurrence and Metastasis of Radiotherapy-Resistant Cancer Stem Cells. Int. J. Mol. Sci. 2017, 18, 1093. [CrossRef] [PubMed]

23. Aypar, U.; Morgan, W.F.; Baulch, J.E. Radiation-induced genomic instability: Are epigenetic mechanisms the missing link? Int. J. Radiat. Biol. 2011, 87, 179-191. [CrossRef] [PubMed]

24. Andreassen, C.N.; Alsner, J. Genetic variants and normal tissue toxicity after radiotherapy: A systematic review. Radiother. Oncol. 2009, 92, 299-309. [CrossRef] [PubMed]

25. De Ruysscher, D.; Severin, D.; Barnes, E.; Baumann, M.; Bristow, R.; Gregoire, V.; Holscher, T.; Veninga, T.; Polanski, A.; van Veen, E.B.; et al. First report on the patient database for the identification of the genetic pathways involved in patients over-reacting to radiotherapy: GENEPI-II. Radiother. Oncol. 2010, 97, 36-39. [CrossRef] [PubMed]

26. Hendry, J.H. Genomic instability: Potential contributions to tumour and normal tissue response, and second tumours, after radiotherapy. Radiother. Oncol. 2001, 59, 117-126. [CrossRef]

27. Whitfield, B.L.; Billen, D. In vivo methylation of Escherichia coli DNA following ultraviolet and X-irradiation. J. Mol. Biol. 1972, 63, 363-372. [CrossRef]

28. Rakova, I.A. Methylation of newly synthesized DNA in rat bone marrow and thymus after irradiation. Radiobiologiia 1979, 19, 413-416. [PubMed]

29. Kalinich, J.F.; Catravas, G.N.; Snyder, S.L. The effect of gamma radiation on DNA methylation. Radiat. Res. 1989, 117, 185-197. [CrossRef] [PubMed]

30. Kovalchuk, O.; Burke, P.; Besplug, J.; Slovack, M.; Filkowski, J.; Pogribny, I. Methylation changes in muscle and liver tissues of male and female mice exposed to acute and chronic low-dose X-ray-irradiation. Mutat. Res. 2004, 548, 75-84. [CrossRef] [PubMed]

31. Pogribny, I.; Raiche, J.; Slovack, M.; Kovalchuk, O. Dose-dependence, sex- and tissue-specificity, and persistence of radiation-induced genomic DNA methylation changes. Biochem. Biophys. Res. Commun. 2004, 320, 1253-1261. [CrossRef] [PubMed]

32. Giotopoulos, G.; McCormick, C.; Cole, C.; Zanker, A.; Jawad, M.; Brown, R.; Plumb, M. DNA methylation during mouse hemopoietic differentiation and radiation-induced leukemia. Exp. Hematol. 2006, 34, 1462-1470. [CrossRef] [PubMed]

33. Loree, J.; Koturbash, I.; Kutanzi, K.; Baker, M.; Pogribny, I.; Kovalchuk, O. Radiation-induced molecular changes in rat mammary tissue: Possible implications for radiation-induced carcinogenesis. Int. J. Radiat. Biol. 2006, 82, 805-815. [CrossRef] [PubMed]

34. Koturbash, I.; Pogribny, I.; Kovalchuk, O. Stable loss of global DNA methylation in the radiation-target tissue-A possible mechanism contributing to radiation carcinogenesis? Biochem. Biophys. Res. Commun. 2005, 337, 526-533. [CrossRef] [PubMed]

35. Antwih, D.A.; Gabbara, K.M.; Lancaster, W.D.; Ruden, D.M.; Zielske, S.P. Radiation-induced epigenetic DNA methylation modification of radiation-response pathways. Epigenetics 2013, 8, 839-848. [CrossRef] [PubMed]

36. Pogribny, I.; Koturbash, I.; Tryndyak, V.; Hudson, D.; Stevenson, S.M.; Sedelnikova, O.; Bonner, W.; Kovalchuk, O. Fractionated low-dose radiation exposure leads to accumulation of DNA damage and profound alterations in DNA and histone methylation in the murine thymus. Mol. Cancer Res. 2005, 3, 553-561. [CrossRef] [PubMed] 
37. Raiche, J.; Rodriguez-Juarez, R.; Pogribny, I.; Kovalchuk, O. Sex- and tissue-specific expression of maintenance and de novo DNA methyltransferases upon low dose X-irradiation in mice. Biochem. Biophys. Res. Commun. 2004, 325, 39-47. [CrossRef] [PubMed]

38. Koturbash, I.; Zemp, F.; Kolb, B.; Kovalchuk, O. Sex-specific radiation-induced microRNAome responses in the hippocampus, cerebellum and frontal cortex in a mouse model. Mutat. Res. 2011, 722, 114-118. [CrossRef] [PubMed]

39. Koturbash, I.; Boyko, A.; Rodriguez-Juarez, R.; McDonald, R.J.; Tryndyak, V.P.; Kovalchuk, I.; Pogribny, I.P.; Kovalchuk, O. Role of epigenetic effectors in maintenance of the long-term persistent bystander effect in spleen in vivo. Carcinogenesis 2007, 28, 1831-1838. [CrossRef] [PubMed]

40. Ilnytskyy, Y.; Koturbash, I.; Kovalchuk, O. Radiation-induced bystander effects in vivo are epigenetically regulated in a tissue-specific manner. Environ. Mol. Mutagen. 2009, 50, 105-113. [CrossRef] [PubMed]

41. Kuhmann, C.; Weichenhan, D.; Rehli, M.; Plass, C.; Schmezer, P.; Popanda, O. DNA methylation changes in cells regrowing after fractioned ionizing radiation. Radiother. Oncol. 2011, 101, 116-121. [CrossRef] [PubMed]

42. Bennett, K.L.; Lee, W.; Lamarre, E.; Zhang, X.; Seth, R.; Scharpf, J.; Hunt, J.; Eng, C. HPV status-independent association of alcohol and tobacco exposure or prior radiation therapy with promoter methylation of FUSSEL18, EBF3, IRX1, and SEPT9, but not SLC5A8, in head and neck squamous cell carcinomas. Genes Chromosomes Cancer 2010, 49, 319-326. [PubMed]

43. Hegi, M.E.; Liu, L.; Herman, J.G.; Stupp, R.; Wick, W.; Weller, M.; Mehta, M.P.; Gilbert, M.R. Correlation of O6-methylguanine methyltransferase (MGMT) promoter methylation with clinical outcomes in glioblastoma and clinical strategies to modulate MGMT activity. J. Clin. Oncol. 2008, 26, 4189-4199. [CrossRef] [PubMed]

44. Hegi, M.E.; Diserens, A.C.; Gorlia, T.; Hamou, M.F.; de Tribolet, N.; Weller, M.; Kros, J.M.; Hainfellner, J.A.; Mason, W.; Mariani, L.; et al. MGMT gene silencing and benefit from temozolomide in glioblastoma. N. Engl. J. Med. 2005, 352, 997-1003. [CrossRef] [PubMed]

45. Olson, R.A.; Brastianos, P.K.; Palma, D.A. Prognostic and predictive value of epigenetic silencing of MGMT in patients with high grade gliomas: A systematic review and meta-analysis. J. Neurooncol. 2011, 105, 325-335. [CrossRef] [PubMed]

46. Narayan, G.; Arias-Pulido, H.; Koul, S.; Vargas, H.; Zhang, F.F.; Villella, J.; Schneider, A.; Terry, M.B.; Mansukhani, M.; Murty, V.V. Frequent promoter methylation of CDH1, DAPK, RARB, and HIC1 genes in carcinoma of cervix uteri: Its relationship to clinical outcome. Mol. Cancer 2003, 2, 24. [CrossRef] [PubMed]

47. Kontic, M.; Stojsic, J.; Jovanovic, D.; Bunjevacki, V.; Ognjanovic, S.; Kuriger, J.; Puumala, S.; Nelson, H.H. Aberrant promoter methylation of CDH13 and MGMT genes is associated with clinicopathologic characteristics of primary non-small-cell lung carcinoma. Clin. Lung Cancer 2012, 13, 297-303. [CrossRef] [PubMed]

48. Belinsky, S.A.; Klinge, D.M.; Liechty, K.C.; March, T.H.; Kang, T.; Gilliland, F.D.; Sotnic, N.; Adamova, G.; Rusinova, G.; Telnov, V. Plutonium targets the p16 gene for inactivation by promoter hypermethylation in human lung adenocarcinoma. Carcinogenesis 2004, 25, 1063-1067. [CrossRef] [PubMed]

49. Song, W.; Liu, Y.; Liu, Y.; Zhang, C.; Yuan, B.; Zhang, L.; Sun, S. Increased p16 DNA methylation in mouse thymic lymphoma induced by irradiation. PLoS ONE 2014, 9, e93850. [CrossRef] [PubMed]

50. Torquati, A.; O'Rear, L.; Longobardi, L.; Spagnoli, A.; Richards, W.O. Daniel Beauchamp, R.; RUNX3 inhibits cell proliferation and induces apoptosis by reinstating transforming growth factor beta responsiveness in esophageal adenocarcinoma cells. Surgery 2004, 136, 310-316. [CrossRef] [PubMed]

51. Chi, X.Z.; Yang, J.O.; Lee, K.Y.; Ito, K.; Sakakura, C.; Li, Q.L.; Kim, H.R.; Cha, E.J.; Lee, Y.H.; Kaneda, A.; et al.

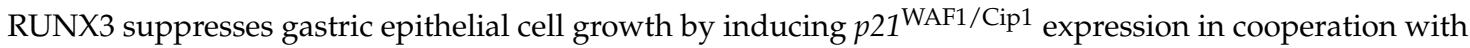
transforming growth factor $\beta$-activated SMAD. Mol. Cell. Biol. 2005, 25, 8097-8107. [CrossRef] [PubMed]

52. Sakakura, C.; Miyagawa, K.; Fukuda, K.I.; Nakashima, S.; Yoshikawa, T.; Kin, S.; Nakase, Y.; Ida, H.; Yazumi, S.; Yamagishi, H.; et al. Frequent silencing of RUNX3 in esophageal squamous cell carcinomas is associated with radioresistance and poor prognosis. Oncogene 2007, 26, 5927-5938. [CrossRef] [PubMed]

53. Liu, S.S.; Leung, R.C.; Chan, K.Y.; Chiu, P.M.; Cheung, A.N.; Tam, K.F.; Ng, T.Y.; Wong, L.C.; Ngan, H.Y. p73 expression is associated with the cellular radiosensitivity in cervical cancer after radiotherapy. Clin. Cancer Res. 2004, 10, 3309-3316. [CrossRef] [PubMed]

54. De Schutter, H.; Geeraerts, H.; Verbeken, E.; Nuyts, S. Promoter methylation of TIMP3 and CDH1 predicts better outcome in head and neck squamous cell carcinoma treated by radiotherapy only. Oncol. Rep. 2009, 21, 507-513. [PubMed] 
55. Chen, X.; Liu, L.; Mims, J.; Punska, E.C.; Williams, K.E.; Zhao, W.; Arcaro, K.F.; Tsang, A.W.; Zhou, X.; Furdui, C.M. Analysis of DNA methylation and gene expression in radiation-resistant head and neck tumors. Epigenetics 2015, 10, 545-561. [CrossRef] [PubMed]

56. Esteller, M.; Garcia-Foncillas, J.; Andion, E.; Goodman, S.N.; Hidalgo, O.F.; Vanaclocha, V.; Baylin, S.B.; Herman, J.G. Inactivation of the DNA-repair gene MGMT and the clinical response of gliomas to alkylating agents. N. Engl. J. Med. 2000, 343, 1350-1354. [CrossRef] [PubMed]

57. Rivera, A.L.; Pelloski, C.E.; Gilbert, M.R.; Colman, H.; De La Cruz, C.; Sulman, E.P.; Bekele, B.N.; Aldape, K.D. MGMT promoter methylation is predictive of response to radiotherapy and prognostic in the absence of adjuvant alkylating chemotherapy for glioblastoma. Neuro Oncol. 2010, 12, 116-121. [CrossRef] [PubMed]

58. Niyazi, M.; Schnell, O.; Suchorska, B.; Schwarz, S.B.; Ganswindt, U.; Geisler, J.; Bartenstein, P.; Kreth, F.W.; Tonn, J.C.; Eigenbrod, S.; et al. FET-PET assessed recurrence pattern after radio-chemotherapy in newly diagnosed patients with glioblastoma is influenced by MGMT methylation status. Radiother. Oncol. 2012, 104, 78-82. [CrossRef] [PubMed]

59. Hashimoto, K.; Narita, Y.; Matsushita, Y.; Miyakita, Y.; Ono, M.; Kayama, T.; Shibui, S. Methylation status of O6-methylguanine-DNA-methyl transferase promoter region in non-small-cell lung cancer patients with brain metastasis. Clin. Transl. Oncol. 2012, 14, 31-35. [CrossRef] [PubMed]

60. Su, S.; Jin, Y.; Zhang, W.; Yang, L.; Shen, Y.; Cao, Y.; Tong, J. Aberrant promoter methylation of $p 16^{\mathrm{INK} 4 \mathrm{a}}$ and $\mathrm{O}^{6}$-methylguanine-DNA methyltransferase genes in workers at a Chinese uranium mine. J. Occup. Health 2006, 48, 261-266. [CrossRef] [PubMed]

61. Nikolaidis, G.; Raji, O.Y.; Markopoulou, S.; Gosney, J.R.; Bryan, J.; Warburton, C.; Walshaw, M.; Sheard, J.; Field, J.K.; Liloglou, T. DNA methylation biomarkers offer improved diagnostic efficiency in lung cancer. Cancer Res. 2012, 72, 5692-5701. [CrossRef] [PubMed]

62. Kim, E.H.; Park, A.K.; Dong, S.M.; Ahn, J.H.; Park, W.Y. Global analysis of CpG methylation reveals epigenetic control of the radiosensitivity in lung cancer cell lines. Oncogene 2010, 29, 4725-4731. [CrossRef] [PubMed]

63. Hamilton, J.P.; Sato, F.; Greenwald, B.D.; Suntharalingam, M.; Krasna, M.J.; Edelman, M.J.; Doyle, A.; Berki, A.T.; Abraham, J.M.; Mori, Y.; et al. Promoter methylation and response to chemotherapy and radiation in esophageal cancer. Clin. Gastroenterol. Hepatol. 2006, 4, 701-708. [CrossRef] [PubMed]

64. Wang, S.; Zhang, R.; Claret, F.X.; Yang, H. Involvement of microRNA-24 and DNA methylation in resistance of nasopharyngeal carcinoma to ionizing radiation. Mol. Cancer Ther. 2014, 13, 3163-3174. [CrossRef] [PubMed]

65. Lin, H.Y.; Hung, S.K.; Lee, M.S.; Chiou, W.Y.; Huang, T.T.; Tseng, C.E.; Shih, L.Y.; Lin, R.I.; Lin, J.M.; Lai, Y.H.; et al. DNA methylome analysis identifies epigenetic silencing of FHIT as a determining factor for radiosensitivity in oral cancer: An outcome-predicting and treatment-implicating study. Oncotarget 2015, 6, 915-934. [CrossRef] [PubMed]

66. Blazek, E.R.; Foutch, J.L.; Maki, G. Daoy medulloblastoma cells that express CD133 are radioresistant relative to CD133- cells, and the CD133+ sector is enlarged by hypoxia. Int. J. Radiat. Oncol. Biol. Phys. 2007, 67, 1-5. [CrossRef] [PubMed]

67. De Jong, M.C.; Pramana, J.; van der Wal, J.E.; Lacko, M.; Peutz-Kootstra, C.J.; de Jong, J.M.; Takes, R.P.; Kaanders, J.H.; van der Laan, B.F.; Wachters, J.; et al. CD44 expression predicts local recurrence after radiotherapy in larynx cancer. Clin. Cancer Res. 2010, 16, 5329-5338. [CrossRef] [PubMed]

68. Du, Z.; Qin, R.; Wei, C.; Wang, M.; Shi, C.; Tian, R.; Peng, C. Pancreatic cancer cells resistant to chemoradiotherapy rich in "stem-cell-like" tumor cells. Dig. Dis. Sci. 2011, 56, 741-750. [CrossRef] [PubMed]

69. Armstrong, C.A.; Jones, G.D.; Anderson, R.; Iyer, P.; Narayanan, D.; Sandhu, J.; Singh, R.; Talbot, C.J.; Tufarelli, C. DNMTs are required for delayed genome instability caused by radiation. Epigenetics 2012, 7, 892-902. [CrossRef] [PubMed]

70. Koturbash, I.; Baker, M.; Loree, J.; Kutanzi, K.; Hudson, D.; Pogribny, I.; Sedelnikova, O.; Bonner, W.; Kovalchuk, O. Epigenetic dysregulation underlies radiation-induced transgenerational genome instability in vivo. Int. J. Radiat. Oncol. Biol. Phys. 2006, 66, 327-330. [CrossRef] [PubMed]

71. Zhu, B.; Huang, X.; Chen, J.; Lu, Y.; Chen, Y.; Zhao, J. Methylation changes of H19 gene in sperms of X-irradiated mouse and maintenance in offspring. Biochem. Biophys. Res. Commun. 2006, 340, 83-89. [CrossRef] [PubMed] 
72. Kwon, H.M.; Kang, E.J.; Kang, K.; Kim, S.D.; Yang, K.; Yi, J.M. Combinatorial effects of an epigenetic inhibitor and ionizing radiation contribute to targeted elimination of pancreatic cancer stem cell. Oncotarget 2017, 8 , 89005-89020. [CrossRef] [PubMed]

73. Hellebrekers, D.M.; Griffioen, A.W.; van Engeland, M. Dual targeting of epigenetic therapy in cancer. Biochim. Biophys. Acta 2007, 1775, 76-91. [CrossRef] [PubMed]

74. Ricketts, C.J.; Morris, M.R.; Gentle, D.; Shuib, S.; Brown, M.; Clarke, N.; Wei, W.; Nathan, P.; Latif, F.; Maher, E.R. Methylation profiling and evaluation of demethylating therapy in renal cell carcinoma. Clin. Epigenetics 2013, 5, 16. [CrossRef] [PubMed]

75. Momparler, R.L.; Cote, S.; Momparler, L.F.; Idaghdour, Y. Epigenetic therapy of acute myeloid leukemia using 5-aza-2'-deoxycytidine (decitabine) in combination with inhibitors of histone methylation and deacetylation. Clin. Epigenetics 2014, 6, 19. [CrossRef] [PubMed]

76. Nervi, C.; De Marinis, E.; Codacci-Pisanelli, G. Epigenetic treatment of solid tumours: A review of clinical trials. Clin. Epigenetics 2015, 7, 127. [CrossRef] [PubMed]

77. Song, S.H.; Han, S.W.; Bang, Y.J. Epigenetic-based therapies in cancer: Progress to date. Drugs 2011, 71, 2391-2403. [CrossRef] [PubMed]

78. Gravina, G.L.; Festuccia, C.; Marampon, F.; Popov, V.M.; Pestell, R.G.; Zani, B.M.; Tombolini, V. Biological rationale for the use of DNA methyltransferase inhibitors as new strategy for modulation of tumor response to chemotherapy and radiation. Mol. Cancer 2010, 9, 305. [CrossRef] [PubMed]

79. Qiu, H.; Yashiro, M.; Shinto, O.; Matsuzaki, T.; Hirakawa, K. DNA methyltransferase inhibitor 5-aza-CdR enhances the radiosensitivity of gastric cancer cells. Cancer Sci. 2009, 100, 181-188. [CrossRef] [PubMed]

80. Hofstetter, B.; Niemierko, A.; Forrer, C.; Benhattar, J.; Albertini, V.; Pruschy, M.; Bosman, F.T.; Catapano, C.V.; Ciernik, I.F. Impact of genomic methylation on radiation sensitivity of colorectal carcinoma. Int. J. Radiat. Oncol. Biol. Phys. 2010, 76, 1512-1519. [CrossRef] [PubMed]

81. Dote, H.; Cerna, D.; Burgan, W.E.; Carter, D.J.; Cerra, M.A.; Hollingshead, M.G.; Camphausen, K.; Tofilon, P.J. Enhancement of in vitro and in vivo tumor cell radiosensitivity by the DNA methylation inhibitor zebularine. Clin. Cancer Res. 2005, 11, 4571-4579. [CrossRef] [PubMed]

82. Chan, A.T.; Tao, Q.; Robertson, K.D.; Flinn, I.W.; Mann, R.B.; Klencke, B.; Kwan, W.H.; Leung, T.W.; Johnson, P.J.; Ambinder, R.F. Azacitidine induces demethylation of the Epstein-Barr virus genome in tumors. J. Clin. Oncol. 2004, 22, 1373-1381. [CrossRef] [PubMed]

83. Desrosiers, R.; Friderici, K.; Rottman, F. Identification of methylated nucleosides in messenger RNA from Novikoff hepatoma cells. Proc. Natl. Acad. Sci. USA 1974, 71, 3971-3975. [CrossRef] [PubMed]

84. Molinie, B.; Wang, J.; Lim, K.S.; Hillebrand, R.; Lu, Z.X.; Van Wittenberghe, N.; Howard, B.D.; Daneshvar, K.; Mullen, A.C.; Dedon, P.; et al. $\mathrm{m}^{6} \mathrm{~A}-\mathrm{LAIC}$-seq reveals the census and complexity of the $\mathrm{m}^{6} \mathrm{~A}$ epitranscriptome. Nat. Methods 2016, 13, 692-698. [CrossRef] [PubMed]

85. Wei, C.M.; Gershowitz, A.; Moss, B. 5'-Terminal and internal methylated nucleotide sequences in HeLa cell mRNA. Biochemistry 1976, 15, 397-401. [CrossRef] [PubMed]

86. Wei, C.M.; Moss, B. Nucleotide sequences at the $N^{6}$-methyladenosine sites of HeLa cell messenger ribonucleic acid. Biochemistry 1977, 16, 1672-1676. [CrossRef] [PubMed]

87. Bokar, J.A.; Shambaugh, M.E.; Polayes, D.; Matera, A.G.; Rottman, F.M. Purification and cDNA cloning of the AdoMet-binding subunit of the human mRNA (N6-adenosine)-methyltransferase. RNA 1997, 3, 1233-1247. [PubMed]

88. Ping, X.L.; Sun, B.F.; Wang, L.; Xiao, W.; Yang, X.; Wang, W.J.; Adhikari, S.; Shi, Y.; Lv, Y.; Chen, Y.S.; et al. Mammalian WTAP is a regulatory subunit of the RNA N6-methyladenosine methyltransferase. Cell Res. 2014, 24, 177-189. [CrossRef] [PubMed]

89. Tuck, M.T. Partial purification of a 6-methyladenine mRNA methyltransferase which modifies internal adenine residues. Biochem. J. 1992, 288, 233-240. [CrossRef] [PubMed]

90. Wang, Y.; Li, Y.; Toth, J.I.; Petroski, M.D.; Zhang, Z.; Zhao, J.C. N6-methyladenosine modification destabilizes developmental regulators in embryonic stem cells. Nat. Cell Biol. 2014, 16, 191-198. [CrossRef] [PubMed]

91. Liu, J.; Yue, Y.; Han, D.; Wang, X.; Fu, Y.; Zhang, L.; Jia, G.; Yu, M.; Lu, Z.; Deng, X.; et al. A METTL3-METTL14 complex mediates mammalian nuclear RNA N6-adenosine methylation. Nat. Chem. Biol. 2014, 10, 93-95. [CrossRef] [PubMed] 
92. Jia, G.; Fu, Y.; Zhao, X.; Dai, Q.; Zheng, G.; Yang, Y.; Yi, C.; Lindahl, T.; Pan, T.; Yang, Y.G.; et al. N6-methyladenosine in nuclear RNA is a major substrate of the obesity-associated FTO. Nat. Chem. Biol. 2011, 7, 885-887. [CrossRef] [PubMed]

93. Zheng, G.; Dahl, J.A.; Niu, Y.; Fedorcsak, P.; Huang, C.M.; Li, C.J.; Vagbo, C.B.; Shi, Y.; Wang, W.L.; Song, S.H.; et al. ALKBH5 is a mammalian RNA demethylase that impacts RNA metabolism and mouse fertility. Mol. Cell 2013, 49, 18-29. [CrossRef] [PubMed]

94. Dominissini, D.; Moshitch-Moshkovitz, S.; Schwartz, S.; Salmon-Divon, M.; Ungar, L.; Osenberg, S.; Cesarkas, K.; Jacob-Hirsch, J.; Amariglio, N.; Kupiec, M.; et al. Topology of the human and mouse m6A RNA methylomes revealed by m6A-seq. Nature 2012, 485, 201-206. [CrossRef] [PubMed]

95. Wang, X.; Lu, Z.; Gomez, A.; Hon, G.C.; Yue, Y.; Han, D.; Fu, Y.; Parisien, M.; Dai, Q.; Jia, G.; et al. N6-methyladenosine-dependent regulation of messenger RNA stability. Nature 2014, 505, 117-120. [CrossRef] [PubMed]

96. Wei, C.M.; Gershowitz, A.; Moss, B. Methylated nucleotides block $5^{\prime}$ terminus of HeLa cell messenger RNA. Cell 1975, 4, 379-386. [CrossRef]

97. Ke, S.; Alemu, E.A.; Mertens, C.; Gantman, E.C.; Fak, J.J.; Mele, A.; Haripal, B.; Zucker-Scharff, I.; Moore, M.J.; Park, C.Y.; et al. A majority of m6A residues are in the last exons, allowing the potential for $3^{\prime}$ UTR regulation. Genes Dev. 2015, 29, 2037-2053. [CrossRef] [PubMed]

98. Batista, P.J.; Molinie, B.; Wang, J.; Qu, K.; Zhang, J.; Li, L.; Bouley, D.M.; Lujan, E.; Haddad, B.; Daneshvar, K.; et al. $\mathrm{m}^{6} \mathrm{~A}$ RNA modification controls cell fate transition in mammalian embryonic stem cells. Cell Stem Cell 2014, 15, 707-719. [CrossRef] [PubMed]

99. Xu, C.; Liu, K.; Tempel, W.; Demetriades, M.; Aik, W.; Schofield, C.J.; Min, J. Structures of human ALKBH5 demethylase reveal a unique binding mode for specific single-stranded N6-methyladenosine RNA demethylation. J. Biol. Chem. 2014, 289, 17299-17311. [CrossRef] [PubMed]

100. Chen, B.; Ye, F.; Yu, L.; Jia, G.; Huang, X.; Zhang, X.; Peng, S.; Chen, K.; Wang, M.; Gong, S.; et al. Development of cell-active N6-methyladenosine RNA demethylase FTO inhibitor. J. Am. Chem. Soc. 2012, 134, 17963-17971. [CrossRef] [PubMed]

101. Chen, W.; Zhang, L.; Zheng, G.; Fu, Y.; Ji, Q.; Liu, F.; Chen, H.; He, C. Crystal structure of the RNA demethylase ALKBH5 from zebrafish. FEBS Lett. 2014, 588, 892-898. [CrossRef] [PubMed]

102. Huang, Y.; Yan, J.; Li, Q.; Li, J.; Gong, S.; Zhou, H.; Gan, J.; Jiang, H.; Jia, G.F.; Luo, C.; et al. Meclofenamic acid selectively inhibits FTO demethylation of $\mathrm{m}^{6}$ A over ALKBH5. Nucleic Acids Res. 2015, 43, 373-384. [CrossRef] [PubMed]

103. Kloor, D.; Osswald, H. S-Adenosylhomocysteine hydrolase as a target for intracellular adenosine action. Trends Pharmacol. Sci. 2004, 25, 294-297. [CrossRef] [PubMed]

104. Tang, C.; Klukovich, R.; Peng, H.; Wang, Z.; Yu, T.; Zhang, Y.; Zheng, H.; Klungland, A.; Yan, W. ALKBH5-dependent m6A demethylation controls splicing and stability of long $3^{\prime}$-UTR mRNAs in male germ cells. Proc. Natl. Acad. Sci. USA 2018, 115, E325-E333. [CrossRef] [PubMed]

105. Zhao, X.; Yang, Y.; Sun, B.F.; Shi, Y.; Yang, X.; Xiao, W.; Hao, Y.J.; Ping, X.L.; Chen, Y.S.; Wang, W.J.; et al. FTO-dependent demethylation of N6-methyladenosine regulates mRNA splicing and is required for adipogenesis. Cell Res. 2014, 24, 1403-1419. [CrossRef] [PubMed]

106. Gordon, R.K.; Ginalski, K.; Rudnicki, W.R.; Rychlewski, L.; Pankaskie, M.C.; Bujnicki, J.M.; Chiang, P.K. Anti-HIV-1 activity of 3-deaza-adenosine analogs. Inhibition of S-adenosylhomocysteine hydrolase and nucleotide congeners. Eur. J. Biochem. 2003, 270, 3507-3517. [CrossRef] [PubMed]

107. Chiang, P.K.; Gordon, R.K.; Tal, J.; Zeng, G.C.; Doctor, B.P.; Pardhasaradhi, K.; McCann, P.P. S-Adenosylmethionine and methylation. FASEB J. 1996, 10, 471-480. [CrossRef] [PubMed]

108. Niu, Y.; Zhao, X.; Wu, Y.S.; Li, M.M.; Wang, X.J.; Yang, Y.G. N6-methyl-adenosine ( $\left.\mathrm{m}^{6} \mathrm{~A}\right)$ in RNA: An old modification with a novel epigenetic function. Genom. Proteom. Bioinform. 2013, 11, 8-17. [CrossRef] [PubMed]

109. Cui, Q.; Shi, H.; Ye, P.; Li, L.; Qu, Q.; Sun, G.; Lu, Z.; Huang, Y.; Yang, C.G.; Riggs, A.D.; et al. $m^{6}$ A RNA Methylation Regulates the Self-Renewal and Tumorigenesis of Glioblastoma Stem Cells. Cell Rep. 2017, 18, 2622-2634. [CrossRef] [PubMed]

110. Wang, X.; Feng, J.; Xue, Y.; Guan, Z.; Zhang, D.; Liu, Z.; Gong, Z.; Wang, Q.; Huang, J.; Tang, C.; et al. Corrigendum: Structural basis of $\mathrm{N}^{6}$-adenosine methylation by the METTL3-METTL14 complex. Nature 2017, 542, 260. [CrossRef] [PubMed] 
111. Sledz, P.; Jinek, M. Structural insights into the molecular mechanism of the $\mathrm{m}^{6} \mathrm{~A}$ writer complex. eLife 2016, 5, e18434. [CrossRef] [PubMed]

112. Wang, P.; Doxtader, K.A.; Nam, Y. Structural Basis for Cooperative Function of Mettl3 and Mettl14 Methyltransferases. Mol. Cell 2016, 63, 306-317. [CrossRef] [PubMed]

113. Zhong, S.; Li, H.; Bodi, Z.; Button, J.; Vespa, L.; Herzog, M.; Fray, R.G. MTA is an Arabidopsis messenger RNA adenosine methylase and interacts with a homolog of a sex-specific splicing factor. Plant Cell 2008, 20, 1278-1288. [CrossRef] [PubMed]

114. Agarwala, S.D.; Blitzblau, H.G.; Hochwagen, A.; Fink, G.R. RNA methylation by the MIS complex regulates a cell fate decision in yeast. PLoS Genet. 2012, 8, e1002732. [CrossRef] [PubMed]

115. Horiuchi, K.; Kawamura, T.; Iwanari, H.; Ohashi, R.; Naito, M.; Kodama, T.; Hamakubo, T. Identification of Wilms' tumor 1-associating protein complex and its role in alternative splicing and the cell cycle. J. Biol. Chem. 2013, 288, 33292-33302. [CrossRef] [PubMed]

116. Schwartz, S.; Mumbach, M.R.; Jovanovic, M.; Wang, T.; Maciag, K.; Bushkin, G.G.; Mertins, P.; Ter-Ovanesyan, D.; Habib, N.; Cacchiarelli, D.; et al. Perturbation of m6A writers reveals two distinct classes of mRNA methylation at internal and 5' sites. Cell Rep. 2014, 8, 284-296. [CrossRef] [PubMed]

117. Fu, Y.; Jia, G.; Pang, X.; Wang, R.N.; Wang, X.; Li, C.J.; Smemo, S.; Dai, Q.; Bailey, K.A.; Nobrega, M.A.; et al. FTO-mediated formation of N6-hydroxymethyladenosine and N6-formyladenosine in mammalian RNA. Nat. Commun. 2013, 4, 1798. [CrossRef] [PubMed]

118. Patil, D.P.; Chen, C.K.; Pickering, B.F.; Chow, A.; Jackson, C.; Guttman, M.; Jaffrey, S.R. m6 A RNA methylation promotes XIST-mediated transcriptional repression. Nature 2016, 537, 369-373. [CrossRef] [PubMed]

119. Pendleton, K.E.; Chen, B.; Liu, K.; Hunter, O.V.; Xie, Y.; Tu, B.P.; Conrad, N.K. The U6 snRNA m ${ }^{6}$ A Methyltransferase METTL16 Regulates SAM Synthetase Intron Retention. Cell 2017, 169, 824-835. [CrossRef] [PubMed]

120. Warda, A.S.; Kretschmer, J.; Hackert, P.; Lenz, C.; Urlaub, H.; Hobartner, C.; Sloan, K.E.; Bohnsack, M.T. Human METTL16 is a $\mathrm{N}^{6}$-methyladenosine $\left(\mathrm{m}^{6} \mathrm{~A}\right)$ methyltransferase that targets pre-mRNAs and various non-coding RNAs. EMBO Rep. 2017, 18, 2004-2014. [CrossRef] [PubMed]

121. Gerken, T.; Girard, C.A.; Tung, Y.C.; Webby, C.J.; Saudek, V.; Hewitson, K.S.; Yeo, G.S.; McDonough, M.A.; Cunliffe, S.; McNeill, L.A.; et al. The obesity-associated FTO gene encodes a 2-oxoglutarate-dependent nucleic acid demethylase. Science 2007, 318, 1469-1472. [CrossRef] [PubMed]

122. Ito, S.; Shen, L.; Dai, Q.; Wu, S.C.; Collins, L.B.; Swenberg, J.A.; He, C.; Zhang, Y. Tet proteins can convert 5-methylcytosine to 5-formylcytosine and 5-carboxylcytosine. Science 2011, 333, 1300-1303. [CrossRef] [PubMed]

123. Mauer, J.; Luo, X.; Blanjoie, A.; Jiao, X.; Grozhik, A.V.; Patil, D.P.; Linder, B.; Pickering, B.F.; Vasseur, J.J.; Chen, Q.; et al. Reversible methylation of $\mathrm{m}^{6} \mathrm{Am}$ in the $5^{\prime}$ cap controls mRNA stability. Nature 2017, 541, 371-375. [CrossRef] [PubMed]

124. Jia, G.; Yang, C.G.; Yang, S.; Jian, X.; Yi, C.; Zhou, Z.; He, C. Oxidative demethylation of 3-methylthymine and 3-methyluracil in single-stranded DNA and RNA by mouse and human FTO. FEBS Lett. 2008, 582, 3313-3319. [CrossRef] [PubMed]

125. Han, Z.; Niu, T.; Chang, J.; Lei, X.; Zhao, M.; Wang, Q.; Cheng, W.; Wang, J.; Feng, Y.; Chai, J. Crystal structure of the FTO protein reveals basis for its substrate specificity. Nature 2010, 464, 1205-1209. [CrossRef] [PubMed]

126. Fu, Y.; Dominissini, D.; Rechavi, G.; He, C. Gene expression regulation mediated through reversible $\mathrm{m}^{6} \mathrm{~A}$ RNA methylation. Nat. Rev. Genet. 2014, 15, 293-306. [CrossRef] [PubMed]

127. Aik, W.; Scotti, J.S.; Choi, H.; Gong, L.; Demetriades, M.; Schofield, C.J.; McDonough, M.A. Structure of human RNA N ${ }^{6}$-methyladenine demethylase ALKBH5 provides insights into its mechanisms of nucleic acid recognition and demethylation. Nucleic Acids Res. 2014, 42, 4741-4754. [CrossRef] [PubMed]

128. Feng, C.; Liu, Y.; Wang, G.; Deng, Z.; Zhang, Q.; Wu, W.; Tong, Y.; Cheng, C.; Chen, Z. Crystal structures of the human RNA demethylase Alkbh5 reveal basis for substrate recognition. J. Biol. Chem. 2014, 289, 11571-11583. [CrossRef] [PubMed]

129. Jacob, R.; Zander, S.; Gutschner, T. The Dark Side of the Epitranscriptome: Chemical Modifications in Long Non-Coding RNAs. Int. J. Mol. Sci. 2017, 18, 2387. [CrossRef] [PubMed]

130. Du, H.; Zhao, Y.; He, J.; Zhang, Y.; Xi, H.; Liu, M.; Ma, J.; Wu, L. YTHDF2 destabilizes m ${ }^{6}$ A-containing RNA through direct recruitment of the CCR4-NOT deadenylase complex. Nat. Commun. 2016, 7, 12626. [CrossRef] [PubMed] 
131. Wang, X.; He, C. Reading RNA methylation codes through methyl-specific binding proteins. RNA Biol. 2014, 11, 669-672. [CrossRef] [PubMed]

132. Li, A.; Chen, Y.S.; Ping, X.L.; Yang, X.; Xiao, W.; Yang, Y.; Sun, H.Y.; Zhu, Q.; Baidya, P.; Wang, X.; et al. Cytoplasmic $\mathrm{m}^{6} \mathrm{~A}$ reader YTHDF3 promotes mRNA translation. Cell Res. 2017, 27, 444-447. [CrossRef] [PubMed]

133. Shi, H.; Wang, X.; Lu, Z.; Zhao, B.S.; Ma, H.; Hsu, P.J.; Liu, C.; He, C. YTHDF3 facilitates translation and decay of $\mathrm{N}^{6}$-methyladenosine-modified RNA. Cell Res. 2017, 27, 315-328. [CrossRef] [PubMed]

134. Wang, X.; Zhao, B.S.; Roundtree, I.A.; Lu, Z.; Han, D.; Ma, H.; Weng, X.; Chen, K.; Shi, H.; He, C. $\mathrm{N}^{6}$-methyladenosine Modulates Messenger RNA Translation Efficiency. Cell 2015, 161, 1388-1399. [CrossRef] [PubMed]

135. Xu, C.; Wang, X.; Liu, K.; Roundtree, I.A.; Tempel, W.; Li, Y.; Lu, Z.; He, C.; Min, J. Structural basis for selective binding of $\mathrm{m}^{6}$ A RNA by the YTHDC1 YTH domain. Nat. Chem. Biol. 2014, 10, 927-929. [CrossRef] [PubMed]

136. Hartmann, A.M.; Nayler, O.; Schwaiger, F.W.; Obermeier, A.; Stamm, S. The interaction and colocalization of Sam68 with the splicing-associated factor YT521-B in nuclear dots is regulated by the Src family kinase p59fyn. Mol. Biol. Cell 1999, 10, 3909-3926. [CrossRef] [PubMed]

137. Xiao, W.; Adhikari, S.; Dahal, U.; Chen, Y.S.; Hao, Y.J.; Sun, B.F.; Sun, H.Y.; Li, A.; Ping, X.L.; Lai, W.Y.; et al. Nuclear m6 Reader YTHDC1 Regulates mRNA Splicing. Mol. Cell 2016, 61, 507-519. [CrossRef] [PubMed]

138. Morohashi, K.; Sahara, H.; Watashi, K.; Iwabata, K.; Sunoki, T.; Kuramochi, K.; Takakusagi, K.; Miyashita, H.; Sato, N.; Tanabe, A.; et al. Cyclosporin A associated helicase-like protein facilitates the association of hepatitis C virus RNA polymerase with its cellular cyclophilin B. PLoS ONE 2011, 6, e18285. [CrossRef] [PubMed]

139. Tanabe, A.; Tanikawa, K.; Tsunetomi, M.; Takai, K.; Ikeda, H.; Konno, J.; Torigoe, T.; Maeda, H.; Kutomi, G.; Okita, K.; et al. RNA helicase YTHDC2 promotes cancer metastasis via the enhancement of the efficiency by which HIF-1 $\alpha$ mRNA is translated. Cancer Lett. 2016, 376, 34-42. [CrossRef] [PubMed]

140. Wojtas, M.N.; Pandey, R.R.; Mendel, M.; Homolka, D.; Sachidanandam, R.; Pillai, R.S. Regulation of $\mathrm{m}^{6} \mathrm{~A}$ Transcripts by the $3^{\prime} \rightarrow 5^{\prime}$ RNA Helicase YTHDC2 Is Essential for a Successful Meiotic Program in the Mammalian Germline. Mol. Cell 2017, 68, 374-387. [CrossRef] [PubMed]

141. Alarcon, C.R.; Goodarzi, H.; Lee, H.; Liu, X.; Tavazoie, S.; Tavazoie, S.F. HNRNPA2B1 Is a Mediator of $\mathrm{m}^{6}$ A-Dependent Nuclear RNA Processing Events. Cell 2015, 162, 1299-1308. [CrossRef] [PubMed]

142. Meyer, K.D.; Patil, D.P.; Zhou, J.; Zinoviev, A.; Skabkin, M.A.; Elemento, O.; Pestova, T.V.; Qian, S.B.; Jaffrey, S.R. 5' UTR m6 A Promotes Cap-Independent Translation. Cell 2015, 163, 999-1010. [CrossRef] [PubMed]

143. Jia, G.; Fu, Y.; He, C. Reversible RNA adenosine methylation in biological regulation. Trends Genet. 2013, 29, 108-115. [CrossRef] [PubMed]

144. Roost, C.; Lynch, S.R.; Batista, P.J.; Qu, K.; Chang, H.Y.; Kool, E.T. Structure and thermodynamics of N6-methyladenosine in RNA: A spring-loaded base modification. J. Am. Chem. Soc. 2015, 137, 2107-2115. [CrossRef] [PubMed]

145. Nallagatla, S.R.; Bevilacqua, P.C. Nucleoside modifications modulate activation of the protein kinase PKR in an RNA structure-specific manner. RNA 2008, 14, 1201-1213. [CrossRef] [PubMed]

146. Liu, N.; Dai, Q.; Zheng, G.; He, C.; Parisien, M.; Pan, T. $\mathrm{N}^{6}$-methyladenosine-dependent RNA structural switches regulate RNA-protein interactions. Nature 2015, 518, 560-564. [CrossRef] [PubMed]

147. Lathia, J.D.; Mack, S.C.; Mulkearns-Hubert, E.E.; Valentim, C.L.; Rich, J.N. Cancer stem cells in glioblastoma. Genes Dev. 2015, 29, 1203-1217. [CrossRef] [PubMed]

148. Zhang, S.; Zhao, B.S.; Zhou, A.; Lin, K.; Zheng, S.; Lu, Z.; Chen, Y.; Sulman, E.P.; Xie, K.; Bogler, O.; et al. $\mathrm{m}^{6}$ A Demethylase ALKBH5 Maintains Tumorigenicity of Glioblastoma Stem-like Cells by Sustaining FOXM1 Expression and Cell Proliferation Program. Cancer Cell 2017, 31, 591-606. [CrossRef] [PubMed]

149. Estey, E.; Dohner, H. Acute myeloid leukaemia. Lancet 2006, 368, 1894-1907. [CrossRef]

150. Vardiman, J.W.; Thiele, J.; Arber, D.A.; Brunning, R.D.; Borowitz, M.J.; Porwit, A.; Harris, N.L.; Le Beau, M.M.; Hellstrom-Lindberg, E.; Tefferi, A.; et al. The 2008 revision of the World Health Organization (WHO) classification of myeloid neoplasms and acute leukemia: Rationale and important changes. Blood 2009, 114, 937-951. [CrossRef] [PubMed] 
151. Marcucci, G.; Yan, P.; Maharry, K.; Frankhouser, D.; Nicolet, D.; Metzeler, K.H.; Kohlschmidt, J.; Mrozek, K.; $\mathrm{Wu}$, Y.Z.; Bucci, D.; et al. Epigenetics meets genetics in acute myeloid leukemia: Clinical impact of a novel seven-gene score. J. Clin. Oncol. 2014, 32, 548-556. [CrossRef] [PubMed]

152. Figueroa, M.E.; Chen, S.C.; Andersson, A.K.; Phillips, L.A.; Li, Y.; Sotzen, J.; Kundu, M.; Downing, J.R.; Melnick, A.; Mullighan, C.G. Integrated genetic and epigenetic analysis of childhood acute lymphoblastic leukemia. J. Clin. Investig. 2013, 123, 3099-3111. [CrossRef] [PubMed]

153. Li, Z.; Weng, H.; Su, R.; Weng, X.; Zuo, Z.; Li, C.; Huang, H.; Nachtergaele, S.; Dong, L.; Hu, C.; et al. FTO Plays an Oncogenic Role in Acute Myeloid Leukemia as a N ${ }^{6}$-Methyladenosine RNA Demethylase. Cancer Cell 2017, 31, 127-141. [CrossRef] [PubMed]

154. Cairns, R.A.; Mak, T.W. Oncogenic isocitrate dehydrogenase mutations: Mechanisms, models, and clinical opportunities. Cancer Discov. 2013, 3, 730-741. [CrossRef] [PubMed]

155. Elkashef, S.M.; Lin, A.P.; Myers, J.; Sill, H.; Jiang, D.; Dahia, P.L.M.; Aguiar, R.C.T. IDH Mutation, Competitive Inhibition of FTO, and RNA Methylation. Cancer Cell 2017, 31, 619-620. [CrossRef] [PubMed]

156. Vu, L.P.; Pickering, B.F.; Cheng, Y.; Zaccara, S.; Nguyen, D.; Minuesa, G.; Chou, T.; Chow, A.; Saletore, Y.; MacKay, M.; et al. The $\mathrm{N}^{6}$-methyladenosine $\left(\mathrm{m}^{6} \mathrm{~A}\right)$-forming enzyme METTL3 controls myeloid differentiation of normal hematopoietic and leukemia cells. Nat. Med. 2017, 23, 1369-1376. [CrossRef] [PubMed]

157. Barbieri, I.; Tzelepis, K.; Pandolfini, L.; Shi, J.; Millan-Zambrano, G.; Robson, S.C.; Aspris, D.; Migliori, V.; Bannister, A.J.; Han, N.; et al. Promoter-bound METTL3 maintains myeloid leukaemia by $\mathrm{m}^{6} \mathrm{~A}$-dependent translation control. Nature 2017, 552, 126-131. [CrossRef] [PubMed]

158. Kwok, C.T.; Marshall, A.D.; Rasko, J.E.; Wong, J.J. Genetic alterations of $\mathrm{m}^{6} \mathrm{~A}$ regulators predict poorer survival in acute myeloid leukemia. J. Hematol. Oncol. 2017, 10, 39. [CrossRef] [PubMed]

159. Siegel, R.L.; Miller, K.D.; Jemal, A. Cancer statistics, 2015. CA Cancer J. Clin. 2015, 65, 5-29. [CrossRef] [PubMed]

160. El-Serag, H.B.; Rudolph, K.L. Hepatocellular carcinoma: Epidemiology and molecular carcinogenesis. Gastroenterology 2007, 132, 2557-2576. [CrossRef] [PubMed]

161. Ma, J.Z.; Yang, F.; Zhou, C.C.; Liu, F.; Yuan, J.H.; Wang, F.; Wang, T.T.; Xu, Q.G.; Zhou, W.P.; Sun, S.H. METTL14 suppresses the metastatic potential of hepatocellular carcinoma by modulating $\mathrm{N}^{6}$-methyladenosine-dependent primary MicroRNA processing. Hepatology 2017, 65, 529-543. [CrossRef] [PubMed]

162. Chen, M.; Wei, L.; Law, C.T.; Tsang, F.H.; Shen, J.; Cheng, C.L.; Tsang, L.H.; Ho, D.W.; Chiu, D.K.; Lee, J.M.; et al. RNA N6-methyladenosine methyltransferase METTL3 promotes liver cancer progression through YTHDF2 dependent post-transcriptional silencing of SOCS2. Hepatology 2017. [CrossRef] [PubMed]

163. Yang, Z.; Li, J.; Feng, G.; Gao, S.; Wang, Y.; Zhang, S.; Liu, Y.; Ye, L.; Li, Y.; Zhang, X. MicroRNA-145 Modulates $\mathrm{N}^{6}$-Methyladenosine Levels by Targeting the $3^{\prime}$-Untranslated mRNA Region of the $\mathrm{N}^{6}$-Methyladenosine Binding YTH Domain Family 2 Protein. J. Biol. Chem. 2017, 292, 3614-3623. [CrossRef] [PubMed]

164. DeSantis, C.E.; Bray, F.; Ferlay, J.; Lortet-Tieulent, J.; Anderson, B.O.; Jemal, A. International Variation in Female Breast Cancer Incidence and Mortality Rates. Cancer Epidemiol. Biomark. Prev. 2015, 24, 1495-1506. [CrossRef] [PubMed]

165. O'Shaughnessy, J. Extending survival with chemotherapy in metastatic breast cancer. Oncologist 2005, 10, 20-29. [CrossRef] [PubMed]

166. Zhang, C.; Samanta, D.; Lu, H.; Bullen, J.W.; Zhang, H.; Chen, I.; He, X.; Semenza, G.L. Hypoxia induces the breast cancer stem cell phenotype by HIF-dependent and ALKBH5-mediated $\mathrm{m}^{6} \mathrm{~A}$-demethylation of NANOG mRNA. Proc. Natl. Acad. Sci. USA 2016, 113, E2047-E2056. [CrossRef] [PubMed]

167. Zhang, C.; Zhi, W.I.; Lu, H.; Samanta, D.; Chen, I.; Gabrielson, E.; Semenza, G.L. Hypoxia-inducible factors regulate pluripotency factor expression by ZNF217- and ALKBH5-mediated modulation of RNA methylation in breast cancer cells. Oncotarget 2016, 7, 64527-64542. [CrossRef] [PubMed]

168. Znaor, A.; Lortet-Tieulent, J.; Laversanne, M.; Jemal, A.; Bray, F. International variations and trends in renal cell carcinoma incidence and mortality. Eur. Urol. 2015, 67, 519-530. [CrossRef] [PubMed]

169. Bielecka, Z.F.; Czarnecka, A.M.; Szczylik, C. Genomic Analysis as the First Step toward Personalized Treatment in Renal Cell Carcinoma. Front. Oncol. 2014, 4, 194. [CrossRef] [PubMed]

170. Li, X.; Tang, J.; Huang, W.; Wang, F.; Li, P.; Qin, C.; Qin, Z.; Zou, Q.; Wei, J.; Hua, L.; et al. The M6A methyltransferase METTL3: Acting as a tumor suppressor in renal cell carcinoma. Oncotarget 2017, 8, 96103-96116. [CrossRef] [PubMed] 
171. Sankaranarayanan, R.; Ferlay, J. Worldwide burden of gynaecological cancer: The size of the problem. Best Pract. Res. Clin. Obstet. Gynaecol. 2006, 20, 207-225. [CrossRef] [PubMed]

172. Waldmann, A.; Eisemann, N.; Katalinic, A. Epidemiology of Malignant Cervical, Corpus Uteri and Ovarian Tumours-Current Data and Epidemiological Trends. Geburtshilfe Frauenheilkund. 2013, 73, 123-129. [CrossRef] [PubMed]

173. Wang, X.; Li, Z.; Kong, B.; Song, C.; Cong, J.; Hou, J.; Wang, S. Reduced $\mathrm{m}^{6} \mathrm{~A}$ mRNA methylation is correlated with the progression of human cervical cancer. Oncotarget 2017, 8, 98918-98930. [PubMed]

174. Bader, J.P.; Brown, N.R.; Chiang, P.K.; Cantoni, G.L. 3-Deazaadenosine, an inhibitor of adenosylhomocysteine hydrolase, inhibits reproduction of Rous sarcoma virus and transformation of chick embryo cells. Virology 1978, 89, 494-505. [CrossRef]

175. Mayers, D.L.; Mikovits, J.A.; Joshi, B.; Hewlett, I.K.; Estrada, J.S.; Wolfe, A.D.; Garcia, G.E.; Doctor, B.P.; Burke, D.S.; Gordon, R.K.; et al. Anti-human immunodeficiency virus 1 (HIV-1) activities of 3-deazaadenosine analogs: Increased potency against 3'-azido-3'-deoxythymidine-resistant HIV-1 strains. Proc. Natl. Acad. Sci. USA 1995, 92, 215-219. [CrossRef] [PubMed]

(C) 2018 by the authors. Licensee MDPI, Basel, Switzerland. This article is an open access article distributed under the terms and conditions of the Creative Commons Attribution (CC BY) license (http:/ / creativecommons.org/licenses/by/4.0/). 